\title{
Environmental and institutional degradation in the globalized economy: lessons from small-scale fisheries in the Gulf of California
}

\author{
Timothy H. Frawley $^{1}$, Elena M. Finkbeiner ${ }^{1,2}$ and Larry B. Crowder ${ }^{1}$
}

\begin{abstract}
External drivers increasingly impact small-scale fisheries worldwide. As globalization accelerates the flow of information, commodities, and capital across geographic space, neoliberal reforms have fueled the development of the international seafood trade. Small-scale fisheries traditionally driven by local forces and market demands are increasingly nested within the broader structures of global markets and international institutions. Building on existing work that integrates social-ecological systems thinking and critical social science theory, we address how globalization has transformed the social fabric of coastal fishing communities and consider the implications for institutional and environmental integrity. Using small-scale fisheries across the Gulf of California as an empirical example, we extend a theory of small-scale fisheries interactions proposed by development scholars to incorporate global market forces, considering how drivers operating at multiple temporal and geographic scales have influenced outcomes in one of the world's most diverse and productive marine ecosystems. We suggest that neoliberal reforms promoting the growth and development of an exportoriented seafood industry have restructured the relationships between small-scale fishermen, coastal communities, and the marine environment. As the benefits of trade liberalization have been captured by local elites, small-scale fishermen have been left increasingly vulnerable to the shocks and uncertainties associated with political, economic, and environmental change. By situating our findings within an emerging body of scholarship documenting parallel dynamics across diverse geographies, we argue that efforts to avoid and/ or mitigate the tragedy of the commons within small-scale fishery systems must address the relationships between global markets, social and economic inequality, and local capacities for self-organization and collective action.
\end{abstract}

Key Words: globalization; Gulf of California; neoliberal reform, small-scale fisheries; social-ecological systems

\section{INTRODUCTION}

Traditional explanations for the challenges of fisheries management are based on the idea that common-pool resources are inherently unmanageable (Gordon 1954, Hardin 1968). Such logic suggests that the two fundamental characteristics of common-pool resources, low excludability and high subtractability, will inevitably result in overexploitation unless those resources are privatized and/or regulated by the government (Feeny et al. 1990, Costello et al. 2008). However, these arguments for topdown management typically ignore local institutions and fail to recognize the value of local participation in management (Berkes et al. 1989). Current common-pool resource theory is based in large part upon the work of Elinor Ostrom (et al. 1994, 2009) who argued that while the tragedy of the commons may occur when resource harvesters are diverse, do not communicate, and fail to develop rules and norms, alternative models for self-organization exist that enable harvesters and local leaders to effectively manage common-pool marine resources (McCay and Acheson 1990, Berkes et al. 1989, Bromley and Feeny 1992). Building on institutional analysis and development frameworks, socialecological systems (SES) thinking arose from the belief that the delineation between resource systems and associated social systems is artificial and arbitrary (Berkes et al. 1998). Rather than focusing on discrete resources, SES focuses its lens upon the highlevel characteristics and processes that enable a system to maintain its core attributes and capacity to regenerate. Fisheries have traditionally been organized to maximize economic output and efficiency (allowable catch, ex-vessel value, etc.). However, decision makers are increasingly being called upon to recognize the complex, multidimensional relationships and feedback mechanisms that link biophysical change and human response
(Pinsky and Fogarty 2012, Salas and Gaertner 2004) and consider how local social-ecological context can impact the adoption and implementation of sustainable management strategies in smallscale fisheries (McClanahan et al. 2009).

Small-scale fisheries (SSF), as defined by labor intensive harvesting strategies, small boats, low relative catch per vessel, and limited capital investment, employ over $90 \%$ of the world's capture fishers and provide livelihoods and food security for many millions of individuals around the globe (Berkes et al. 2001), especially in developing and postdevelopmental countries (Béné et al. 2007). Such fisheries frequently revolve around extraction of heterogeneous resources by fishers who employ diverse livelihood strategies (Ostrom et al. 1994, Allison and Ellis 2001). In regions where formal regulatory capacity is weak or is focused primarily on the industrial sector, patterns of SSF production, commercialization, and governance may be structured by a diverse array of self-organized arrangements (Chuenpagdee 2011). The Gulf of California is a unique and highly productive marine environment that contributes more than half the national value of Mexican fisheries on an annual basis (Carvajal et al. 2004). This productivity has attracted waves of human migrants from other parts of Mexico. Depending on the season, anywhere from 10,000 to 24,000 small-scale fishing vessels provide food and labor opportunities for over 50,000 individuals (Cisneros-Mata 2010). Following several decades of neoliberal reform, the sector has been shaped by economic incentives from global markets and the international seafood trade. Caught in a tug-of-war between laissez-faire management and ecological conservation priorities (Cisneros-Montemayor et al. 2013) small-scale fisheries in Mexico have evolved to reflect the overarching instability of the national political system (Espinoza-Tenorio et al. 2011). Marine resource 
access rights have been consolidated in the hands of local elites as an increasingly large portion of the fishermen actively engaged in harvest are rendered illegal actors that lack incentive to follow best practices for sustainable use (Vásquez-León 1999, Cinti et al. 2010).

The SES approach to management planning has gained significant traction amongst those working in small-scale fisheries throughout the world (Cinner et al. 2009, Aguilera et al. 2015) and in northwest Mexico in particular (Basurto et al. 2013 $a$, Leslie et al. 2015, Naranjo-Madrigal et al. 2015) as researchers seek to identify ecological conditions and demographic characteristics associated with self-organization, collective action, adaptation, and sustainability. But a focus on the interactions between institutions and organized social units does not adequately address the global market forces driving patterns of resource extraction in the modern era. Rather than existing as isolated subsystems, small-scale fisheries worldwide are increasingly affected by external drivers and pressures that jeopardize livelihoods, food security, and traditional cultural practices (Kittinger et al. 2013). Globalization, defined as the accelerated growth of economic activity that spans politically defined national and international boundaries (Oman 1999), has fueled the development of the international seafood trade (Swartz et al. 2010), the commodification of marine resources (Anderson 2003), and the consolidation of fisheries enterprises (Alder and Watson 2007) while potentially undermining local self-sufficiency and regulatory autonomy (Greenberg 2006, Crona et al. 2015). Though recent scholarship has made significant progress in exploring the distributional benefits of the international seafood trade across small-scale fisheries and their relationships with regional economic development (Crona et al. 2016) and institutional response (Bennett and Basurto 2018), further work is required to investigate the implications for livelihoods, food security, and environmental sustainability in diverse socialecological contexts (Finkbeiner et al. 2017). Here we integrate the findings of SES researchers, development scholars, anthropologists, and political economists to improve our understanding of the structure and function of small-scale fisheries in the age of globalization. After grounding our synthesis in pertinent critical theory we (1) describe the evolution of the small-scale fishery sector in the Gulf of California, (2) examine the social-ecological interactions driving environmental and institutional change, and (3) highlight those relationships and feedbacks documented empirically in other systems in order to generalize our findings and advance a unifying theoretical model.

\section{NEOLIBERALISM, GLOBALIZATION, AND THE RISE OF THE MIDDLEMAN}

Neoliberal economic thinking gained traction across Western Europe and North America during the 1970s in response to the interventionism that fueled economic growth following the Second World War (Brenner et al. 2010). For individuals, the tenets of neoliberalism emphasize the value of individual freedom and choice as embodied by the capitalist markets. At the national level, economic growth, free trade, and reduced state regulation assume primary importance (Martin 2005). From the outset, neoliberal regulatory reform and the processes of globalization were inextricably linked. By "rolling back" state control, while amplifying the power of transnational corporations and international lending agencies, neoliberalism has dramatically accelerated the integration of economic processes beyond nationstate boundaries. Across the many contexts in which it has been mobilized, neoliberalism has facilitated market rule and commodification while simultaneously intensifying the uneven development of regulatory forms across places, territories, and scales (Brenner et al. 2010). Enormous scholarly interest in this topic has led to a number of diverse, and at times competing, definitions (Castree 2008a, b, 2010, Brenner et al. 2010). Neoliberalism, like globalization, has been referred to as a "rascal concept," that defies theoretical clarity and methodological precision (Peck and Theodore 2007, Brenner et al. 2010). Enduring tensions exist between depictions of neoliberalism as a monolithic and omnipresent force and case-specific analyses that obscure the substantial connections and necessary characteristics of the phenomenon as an extralocal project (Larner 2000, Peck and Tickell 2002). Below, following a brief review of broadly relevant background literature, we adopt the process-oriented approach advocated by critical geographers and political economists (Peck and Tickell 2002, Mansfield 2004, McCarthy 2006), investigating how the generic and abstract features of neoliberalism manifest within the small-scale fisheries of postcolonial nations as specific policies and practices lead to dominant changes in system structure and function.

In fisheries, neoliberal reform has often led to decentralization and devolution of responsibility for the governance and provision of public goods to nonstate actors. New rights and freedoms were granted to private enterprise and regulations limiting capital accumulation were dismantled (Mansfield 2004). As open access was blamed for economic inefficiency, rent dissipation, and fisheries decline, the politics of privatization gained traction amongst those managing the use of common-pool resources alongside the belief that the free market would regulate the activities of self-interested entrepreneurs (Oman 1999, Pinkerton and Davis 2015). But marine social scientists have long noted the disconnect between fisheries economists' characterization of fishermen as rational actors and the ethnographic record of how fishermen actually behave (McCay and Acheson 1990, Durrenberger 1997, Pollnac and Poggie 2008). Recent scholarship has explored how privatization, commodification, and the new property relationships they create may function to dispossess people from land, sea, and resources (St Martin 2007, Mansfield 2011, Olson 2011, Carothers and Chambers 2012, Pinkerton and Davis 2015). With the development of free trade agreements and implementation of policies promoting export-oriented growth, many fishing rights were recast and commodified as objects that could be bought and sold while mechanisms developed to facilitate the investment of foreign enterprises and corporations. Separated from traditional patterns of social and economic life, many traditional marine resource users have been forced to labor for the owners of capital and newly created commodities (Mansfield 2011, Carothers and Chambers 2012). Neoliberal reforms fueling fisheries privatization and the globalization of the seafood trade have not merely marked an institutional shift, but have fundamentally restructured the relationships between people and the marine environment (Mansfield 2007).

Although neoliberal tendencies are observable everywhere, actual practices are uneven and contingently produced in place-specific ways, interacting with "inherited landscapes" of political, economic, and social conditions (McCarthy 2006, Brenner et al. 
2010). Building upon foundational work that has examined trajectories of neoliberalism and fisheries rationalization across the ideological heartlands of North American and Western Europe (Mansfield 2007, 2011, St. Martin 2007, Olson 2011) we now consider the small-scale fisheries of postcolonial nations. In such regions the advent of neoliberalism has been inextricably tied to narratives of resource scarcity and the promotion of private property rights as interventionist states that historically led the development of natural resource sectors gave way to more austere governance institutions (Bennett 2017). In conjunction with a series of debt crises, currency devaluations and financial upheavals across parts of Latin America, South Asia, and subSaharan Africa, the exhaustion and instability of existing institutional orders created space for regulatory experimentation. Global, multilateral regulatory institutions like the WTO, the IMF, and the World Bank sought to solidify market rule and enhance capital mobility by incentivizing pathways toward commodification (Brenner et al. 2010). The idea was that many unpriced and unowned biophysical assets could be inserted into global markets, creating revenue streams that would support socioeconomic development (Castree 2010). In many regions local fisheries were exposed to international markets for the first time as trade liberalization became a condition for receiving foreign aid (Crona et al. 2016). Many coastal communities were no longer treated as impoverished and egalitarian entities in need of government support or protection, but rather collections of irrational users that required market regulation to use their resources more efficiently (Pinkerton 2017, Altamirano-Jiménez 2017). For its longstanding advocates in the Anglo-American world, neoliberalism represents a kind of self-imposed disciplinary code, embedded within classic economic liberalism, that reveres market logic and fiscal restraint. However, for its converts in the Global South, neoliberalism has assumed a more authoritarian character, "externally imposing unbending rule regimes enforced by global institutions and policed by local functionaries" (Peck and Tickell 2002:381).

Fish trading in small-scale or semi-industrial fisheries is very often organized within an informal context (Bennett 2017). Market intermediaries or middlemen have traditionally enabled fishers to minimize their transaction costs, providing them with a link to external markets and reducing the time and effort needed by producers to market their goods (Acheson 1985, Merlijn 1989, Crona et al. 2010). By engaging in informal arrangements with fish buyers, fishers were able to ensure their access to fishing permits and equipment as well informal loans and subsidies that served as insurance against seasonal and interannual resource fluctuations (Platteau and Abraham 1987, Merlijn 1989). Although monopolistic advantage and exploitative contractual arrangements have long existed in the context of such patronclient relationships (Amarasinghe 1989, Merlijn 1989, Van Mulekom et al. 2006, Peterson 2015), neoliberal reforms and globalization have amplified and legitimized asymmetrical distributions of power (Finkbeiner et al. 2017) and led to an intensification of overfishing, overcapitalization, and conflict (Thorpe et al. 2000). As the international seafood trade has expanded, the linking function of middlemen in the supply chain has enabled them to become critical allies of external agents looking to develop markets and gain access to local stocks for exploitation (Crona et al. 2010). In the modern era, these individuals are often local elites with political-economic connections and capital reserves who possess the potential to undermine social networks that support the emergence and sustainability of collective action (Crona and Bodin 2010).

Relations of production shape patterns of resource use and governance by defining who controls access to resources, capital, and profits (Bennett and Basurto 2018). Capitalist modes of production may have negative effects on resource use when processes of commodification and accumulation push natural resource use beyond sustainable limits (Campling et al. 2012). Fishing cooperatives and other traditional marine tenure systems, organized by the principles of revenue sharing, typically seek to restrict access to fishing grounds. In contrast, fisheries patrons seeking to maximize individual economic gain may facilitate "rules-in-use" that expand local fishing fleets and drive immigration (Fraga et al. 2008), undermining the small group sizes and shared understanding that facilitate successful local selfgovernance (Ostrom 2009). By connecting a heterogeneous base of resource users to global markets and by channeling demands that translate into harvesting pressures, middlemen have significant potential to accelerate resource decline (Crona et al. 2010). Expansion of globalized markets for fisheries species often increases capitalization or specialization for particular local stocks, increasing their susceptibility to over exploitation and reducing the capacity of fishers to shift to alternatives when resources decline (Kittinger et al. 2013). Middlemen face strong economic incentives to supply the demand for fish and do not pay the costs of ecosystem degradation because they can move unrestricted to other areas, acting like "roving bandits" if they so choose (Berkes et al. 2006).

\section{EVOLUTION OF SMALL-SCALE FISHERIES IN THE GULF OF CALIFORNIA}

Since the late 1980s, Mexico's marine fisheries and coastal resources have undergone deep structural transformations as neoliberal reforms have led to the liberalization of markets and the decentralization of state control (Cruz-Torres 2001, Ibarra et al. 2000a, Greenberg 2006). Marine fisheries and coastal resources in the Gulf of California offer an interesting example of how the neoliberal model has subordinated local development efforts and generated intensive exploitation through the process of resource commoditization and privatization (Vásquez-León 2012). Though the stated goals of neoliberal reforms were to sustain economic growth, improve quality of life, and combat poverty, economic benefits of such policy have often been aggregated by local and/or regional elites (Pastor and Wise 1997) at the expense of the livelihoods and well-being of small-scale fishermen (CruzTorres 2000, Greenberg 2006, Vásquez-León 2012), thereby restructuring the relationship between coastal communities and the marine environment (DeWalt 1998). Corruption has proliferated as market intermediaries and administrative officials have taken advantage of political and economic instability to seize control of fishing rights and production processes from traditional cooperatives, running them for personal profit and political gain (Vásquez-León 1999).

\section{History of neoliberal reforms in Mexico}

Following the Mexican Revolution, the 1917 Constitution enshrined rights for Mexico's peasant and working classes. It restored lands stripped from communities by haciendas and plantations and sought to protect Mexico's sovereignty over its lands, waters, and mineral rights (Greenberg et al. 2012). Article 
27 was, "based upon the fundamental theorem that natural resources are part of the public wealth and that state intervention is required to ensure that such wealth is adequately distributed and managed," (Young 2001). In 1935 the Mexican national government declared that all fishing activity would be organized through a system of cooperatives (Bourillón-Moreno 2002) that were progressively awarded exclusive access to many national fish stocks (Ibarra et al. 2000a). Although sea turtle fishing and pearl extraction were considered important economic activities during the century that followed the Mexican War of Independence (Carvajal et al. 2004), it was not until the 1950s that fishing became a major driving force in regional development (Sala et al. 2004). In the 1970 s a series of laws promoted export-oriented fisheries and confirmed the exclusive fishing rights of cooperatives. During this time an estimated 6000 new artisanal vessels entered Mexican fisheries (Ibarra et al. 2000a) as large numbers of immigrants from mainland Mexico settled around networks of highly productive bays and estuaries (Young 2001). Production rose by an average of $10 \%$ per year while seafood exports in aggregate increased eight-fold (Ibarra et al. 2000a). In 1980, an US\$80 million loan from the Inter-American Development Bank was used to establish the state-directed fisheries bank BANPESCA (Banco Nacional Pesquero y Portuario) with the goal of underwriting the cooperative sector while concurrently directing funds toward the expansion of industrial shrimp, tuna, sardine, and anchovy fisheries (Ibarra et al. 2000b).

The booming economic climate that characterized Mexico in the late 1970s gave way to the 1982 debt crisis in much of Latin America as the price of oil slumped and export earnings collapsed (Vásquez-León 1999). This financial crisis coincided with the severe 1982-1983 El Niño event that caused sharp declines in the landings of shrimp, squid, sardines, and other economically important species. Credit became increasingly difficult to obtain across the cooperative sector as BANPESCA found itself holding an estimated US\$1 billion in nonperforming loans (Ibarra et al. $2000 a$ ). As the crisis intensified, Mexico's primary trading partners, including the U.S. and major lenders like the World Bank and the IMF, urged Mexico to downsize the government and privatize the economy (Greenberg 2006). In 1988, the administration of Salinas de Gotari began to restructure the fisheries sector with neoliberal development policies designed to curb the fiscal deficit as boats, canneries, and other essential fishing infrastructure was privatized (Ibarra et al. 2000a). Smallscale fishermen who defaulted upon their loans saw their boats and equipment sold to private capitalists at bargain prices. Though cooperatives maintained exclusive fishing rights, private enterprise assumed control of production processes (Dewalt 1998).

By the early 1990s BANPESCA was liquidated. In 1992, additional neoliberal reforms amended Article 27 of the 1917 Constitution, sanctioning the privatization of communally held property, or ejidos (Breunig 2006). Several months later exclusive harvest rights, historically reserved for fishing cooperatives, were revoked and private interests were granted access to fishery concessions, which became competitive, conditional, and timelimited (McCay et al. 2014). The majority of fishing cooperatives spiraled further into debt, went bankrupt, and were subsequently dismantled (Bourillón-Moreno 2002). Following the privatization of fisheries and other vital economic sectors, Mexico signed the North American Free Trade Agreement (NAFTA) with the U.S. and Canada in 1994, removing any lingering trade barriers and clearing a path for foreign investment (Weintraub 1990, Young 2001, Greenberg et al. 2012). By the end of the year, $90 \%$ of cooperative vessels had been transferred to the private sector (Arena-Fuentes and León-Corral 1997). The majority of Mexican seafood is now exported and official statistics reported in 2003 put the export/import ratio at approximately 2:1 (Espinoza-Tenorio et al. 2011). Although growth of the export fisheries has enabled Mexico to generate foreign exchange, the demand from international markets placed huge pressures on fisheries resources, accelerating user conflicts and destructive and illegal fishing practices (Ibarra et al. 2005, Swartz et al. 2010). Illegal, unregulated, and unreported catch (IUU) is estimated to comprise more than 50\% of total landings in Mexico (CisnerosMontemayor et al. 2013), with the United States importing more than $\$ 130$ million of IUU seafood from Mexico in 2011 alone (Pramod et al. 2014).

\section{Modern structure of small-scale fisheries in the Gulf of California}

In the modern era, the management of small-scale fisheries in the Gulf of California is based upon a limited entry permit system. In theory, any commercial fisher must have a fishing permit, authorization, or concession granted by the government prior to entering any specified marine area and obtaining products from it (Bourillón-Moreno 2002). Fishing permits may be granted to any corporate entity, i.e., cooperative, or individual for two to five years and they are renewable based upon evidence of compliance with regulations (Cinti et al. 2010). It is important to distinguish between those fishing enterprises that are cooperative in name and those that are cooperative in function (Fig. 1). In practice, few of these organizations are cooperatively managed; generally, one individual or family administers the business and concentrates power (Cinti et al. 2010). Although traditional, community cooperatives relied on democratic processes to make decisions, designate responsibilities, and allocate rights, soleowner cooperatives are the result of an individual owning multiple boats and registering his employees as members. Likewise, within the context of family cooperatives, a particular kin network or family head will make decisions even if members include nonrelatives (Avila-Forcada et al. 2012, Finkbeiner 2014).

In practice most private permit holders or permisionarios are buyers that marshal equipment and access rights while hiring independent fishermen, or pescadores libres, as a labor force to carry out the harvest (Cinti et al. 2010). These patrons typically supply fishing boats and gear and provide, in advance, the funds needed to cover trip costs (gas, food, ice, etc.). In exchange, independent fishermen are obligated to sell their catch to the permit holder (Cinti et al. 2010, Basurto et al. 2013b). Whereas proof of ownership of fishing equipment is required to become a private permit holder, active participation as a crew member is not (Cinti et al. 2014). The majority of permisionarios are not fishermen and most are not even from the localities in which they operate (Vásquez-León 2012). This disparate social structure is reinforced by the institutional barriers to obtain fishing permits, a process that requires the submission of exhaustive and time consuming paperwork and navigating the complex, hierarchical network of local officials and bureaucrats (Vásquez-León 1999, Cinti et al .2010). Permisionarios and other fisheries patrons often represent coastal communities in regional and national discourses concerning resource management and environmental protection 
Fig. 1. Small-scale fisheries organizational continuum across northwest Mexico. Although community cooperatives targeting high-value, benthic species, i.e., lobster and abalone, are common across the Pacific Northwest, following several decades of neoliberal reform the labor of free fishermen within the Gulf of California is largely organized via a network of private permit holders (permisionarios).

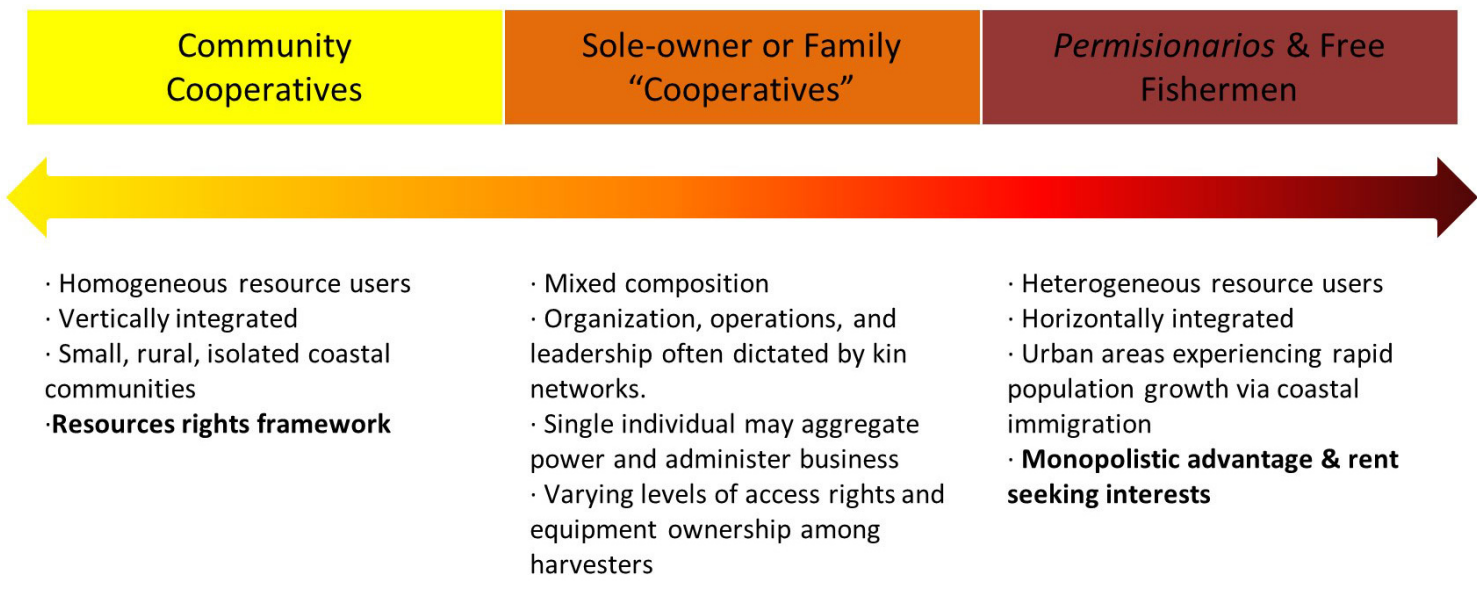

while small-scale fishermen are portrayed as ignorant and irrational users (Cinti et al. 2010, Vásquez-León 2012). As elites have leveraged neoliberal restructuring to aggregate political and economic power, a monopoly market situation has evolved in which some fishermen only interact with a single buyer, reducing their ability to negotiate prices or add value to their catch before sale (Valdez-Gardea 2007, Peterson 2015). Even in cases where multiple fisheries patrons operate within a single community, collusion, i.e., price fixing, may be more common than competition (de la Cruz-González et al. 2011, Finkbeiner 2014).

Functioning of the limited entry system relies heavily upon enforcement, but in practice poor enforcement of fishing laws makes it impossible to control the fishing effort (BourillónMoreno 2002). Federal inspectors may only visit rural communities once or twice a year and information concerning their movements often filters down to fishermen prior to each visit, giving them time to adjust or modify their behavior (Cinti et al. 2014). In practice monitoring and enforcement depends upon the oversight of fishermen that have been deputized to oversee boundaries and regulate compliance (Bourillón-Moreno 2002, McCay et al. 2014). But corruption (Vásquez-León 1999), increasing coastal immigration (Greenberg 2006, Greenberg et al. 2012), and the substantial cost for fishers to organize and participate in collective-action processes (Basurto and Ostrom 2009, Cudney-Bueno and Basurto 2009) have promoted de facto open access (Cinti et al. 2010).

\section{SOCIAL-ECOLOGICAL INTERACTIONS}

In the Gulf of California, traditional fishermen tend to be highly diversified, multiple species, and multiple gear fishers. They possess vast knowledge, transmitted through generations, that allows them to shift fishing strategies in response to species availability during times of crisis (Vasquez-Leon 2002, Sievanen 2014). This flexibility requires a sophisticated understanding of the ecosystem, biology, and behavior of a variety of species, as well as access to a variety of fishing gear and the ability to use it appropriately (Vásquez-León 2012). In small-scale fisheries across Baja California, diverse livelihood strategies are considered a critical component of fisheries resilience and interannual income stability (Finkbeiner 2015).

In the modern era, fishers with knowledge of resource dynamics have less decision-making power as compared to fish buyers, particularly if these patrons provide fishers with fishing permits, credits, and loans for fishing equipment (Basurto et al. 2013b). With the proliferation of rent-seeking interests (Cinti et al. 2010) and the politics of privatization, many fishers have lost access to traditional fishing grounds and species assemblages (Sievanaen 2014). Often permit holders will only activate their distribution networks and employ the full extent of their capital during periods of elevated resource abundance, contracting fishermen to target seasonal aggregations of specific species (Vásquez-León 2012; Frawley personal observation). As long-time fishers retire or are otherwise excluded, those replacing them are increasingly fishing specialists who lack the traditional ecological knowledge and attachment to place that once served to regulate regional resource use (Vásquez-León 1994, Rubio-Cisneros et al. 2017). Fishermen with short-term economic outlooks face compelling incentives to engage in destructive and illegal fishing practices (Cinti et al. 2010, Cruz-Torres 2001) and may be forced to diversify their activities through participation in underground economies (Robles-Zavala 2014). A "culture of piracy" (McCay 1984) has subverted the ideals of cooperative governance (McGoodwin 1987, VásquezLeón 1994); through noncompliance, i.e. poaching, use of prohibited gear, fishing during closed seasons, etc., as an expression of insubordination, members of the small-scale fishing community seek to maintain some semblance of autonomy in spite of their marginal position (Valdez-Gardea 2002).

In the Gulf of California, permisionarios have been known to facilitate the intrusions of outside pangas or roving bandits, fishermen not officially registered or recognized by law, into local fishing zones during periods of particularly profitable harvest, provided that outsiders acknowledge the permisionarios' exclusive right to buy and market their catch (Cudney-Bueno and Basurto 2009, Cinti et al. 2010). Because permit holders are the only ones able to issue the legal invoices required to legitimize 
catch, many are tempted to buy and sell resources caught with boats other than those registered in the permits. This practice of catch sheltering or amparo is widespread (Bourillón-Moreno 2002, Cinti et al. 2010). A conservative estimate, calculated by buyers, is that $50 \%$ of the catch is never registered (BourillónMoreno 2002). Permit holders and independent fishermen are further provided incentive to shelter and/or underreport their catches by the prices that globally demanded seafood can fetch on the black market (Ibarra and Ramírez Soberón 2002). One study on the Pacific coast of Baja California (Reyes et al. 2009) concluded that abalone received and legitimized through official channels would garner fishermen only half the value that could be obtained when the product was sold on the black market. In the Gulf of California, market intermediaries with connections to the black market may channel international demand for high value species like sea cucumber (Ibarra and Ramírez Soberón 2002), turtle (Mancini et. al. 2011), and totoaba (Méndez 2016) regardless of the ethical or environmental implications.

\section{System change}

The history of developing nations, like Mexico, is characterized not by long periods of stability but rather frequent short periods of radical change (Espinoza-Tenorio et al. 2011). During the last half of the 20th century, coastal communities in northwest Mexico have emerged from isolation. As neoliberal economic thinking has increasingly guided national economic development, rural areas have been linked with modern values and global markets. During this transition, many communities have become separated from traditional patterns of social and economic life. Their vulnerability and exposure to a rapidly changing nation has forced them to continually reassess their own values and adjust to new ones imposed from outside their community (McGoodwin 1976). Although fishermen in Mexico acknowledge the developing ecological crisis and an imminent need to reduce effort, they feel that national regulations and policies have failed to address the principal concerns of local communities (VásquezLeón 1999) and the economic, social, and cultural needs of the fishermen who inhabit them (Peterson 2014).

\section{Environmental degradation}

Across the Gulf of California, neoliberal reforms have transferred control of productive coastal zones from regional fishing cooperatives to industrial producers, transnational capital, and market intermediaries. National regulations have increasingly focused on facilitating the investment of foreign capital and subsidizing the development of large export-oriented fisheries and aquaculture operations with limited consideration of ecological (Páez-Osuna et al. 1998, Meltzer et al. 2012), economic (Meltzer and Chang 2006, de la Cruz-González et al. 2011), or social (Vásquez-León 1994, Cruz-Torres 2008, Rubio-Cisneros et al. 2017) costs borne by small-scale producers. Though it is difficult to establish a definitive causal connection between processes of neoliberalism and issues of resource scarcity, it appears evident that shifts toward open markets and the expansion of private capital have incentivized unsustainable behaviors and accelerated overexploitation (Young 2001, Defeo and Castilla 2005, Bennett 2017).

Industrial fisheries, particularly those reliant upon bottom trawling, can be wasteful and environmentally harmful, not only by the removal of biomass and diversity, but also by the significant impact on habitat and the high amount of discards (Alverson et al. 1994). The estimated value of commercial fish species discarded by the Gulf of California shrimp fishery, where bycatch composes $\sim 85 \%$ of the weight of each trawl (Meltzer et al. 2012), is US\$61-103 million per year alone (Ibarra 2017). Within smallscale fisheries, efforts to encourage investments from the private sector have exacerbated problems of outside encroachment, accelerated exploitation rates, and encouraged poaching (Young 2001). Currently, $85 \%$ of the Gulf's fisheries are either at their maximum sustainable yield or overexploited (Cisneros-Mata 2010) and the ecology and biodiversity of the region have suffered considerable degradation (Carvajal et al. 2004). There is clear evidence that coastal food webs in the Gulf of California have been "fished down" during the last 30 years and that the maximum individual length of landed fish has decreased significantly (Sala et al. 2004, Saenz-Arroyo et al. 2005). User conflicts have increased as poverty and resource scarcity have worsened; today many small-scale fishing households are being pressured to the point where marine-dependent livelihoods are becoming unviable (Carvajal et al. 2004, Vásquez-León 2012).

\section{Institutional degradation}

Global market forces facilitating the penetration of capitalism and class processes have progressively eroded the social fabric of coastal fishing communities by amplifying social divisions and economic inequality (Delgado 2013). As short sighted and inconsistent national policies have disproportionately targeted the poor and marginalized (Peterson 2015), unregulated and unsustainable fishing practices have increased (Young 2001, Cinti et al. 2010). Independent fishermen, once fiercely proud of their autonomy and occupational identity, have been subordinated by fisheries patrons while being forced to navigate the selective enforcement of opaque local regulations (Vásquez-León 1999). Deprived of the knowledge and agency required to develop and diversify their activities, fishermen are increasingly concerned with survival rather than sustainability (Cruz-Torres 2001). With competition intensifying for increasingly scarce marine resources, fishing has evolved from a cooperative to an individual activity (Espinoza and Magadán 2010). A neglect of shared values and common responsibilities has undermined the moral economy and interpersonal relationships that once served as the basis for collective action and environmental stewardship (Revelo et al. 2015). Those organizational structures that exist in the modern era represent capitalist enterprises controlled by economic power relations rather than tools for labor organization and social security (Espinoza and Magadán 2010).

\section{SMALL-SCALE FISHERIES IN THE AGE OF GLOBALIZATION}

Small-scale fisheries worldwide are increasingly embedded within the international seafood trade and the political and economic structures that facilitate it. Marine resource licensing and allocation regimes have restricted fishing portfolios (Hilborn et al. 2001, Stoll et al. 2016) as demand from global markets has accelerated the depletion of particular local stocks (Berkes et al. 2006). With many fishers becoming reliant on fewer and fewer species, emergent forms of social-ecological organization are functioning to decouple them from the marine ecosystems upon which they depend (Farr et al. 2018) and the coastal communities of which they are a part (Nayak et al. 2014).

Though proponents of neoliberal reform suggest that globalization and trade liberalization provide new opportunities 
Table 1. Summary of external drivers and processes influencing social-ecological outcomes within the Gulf of California.

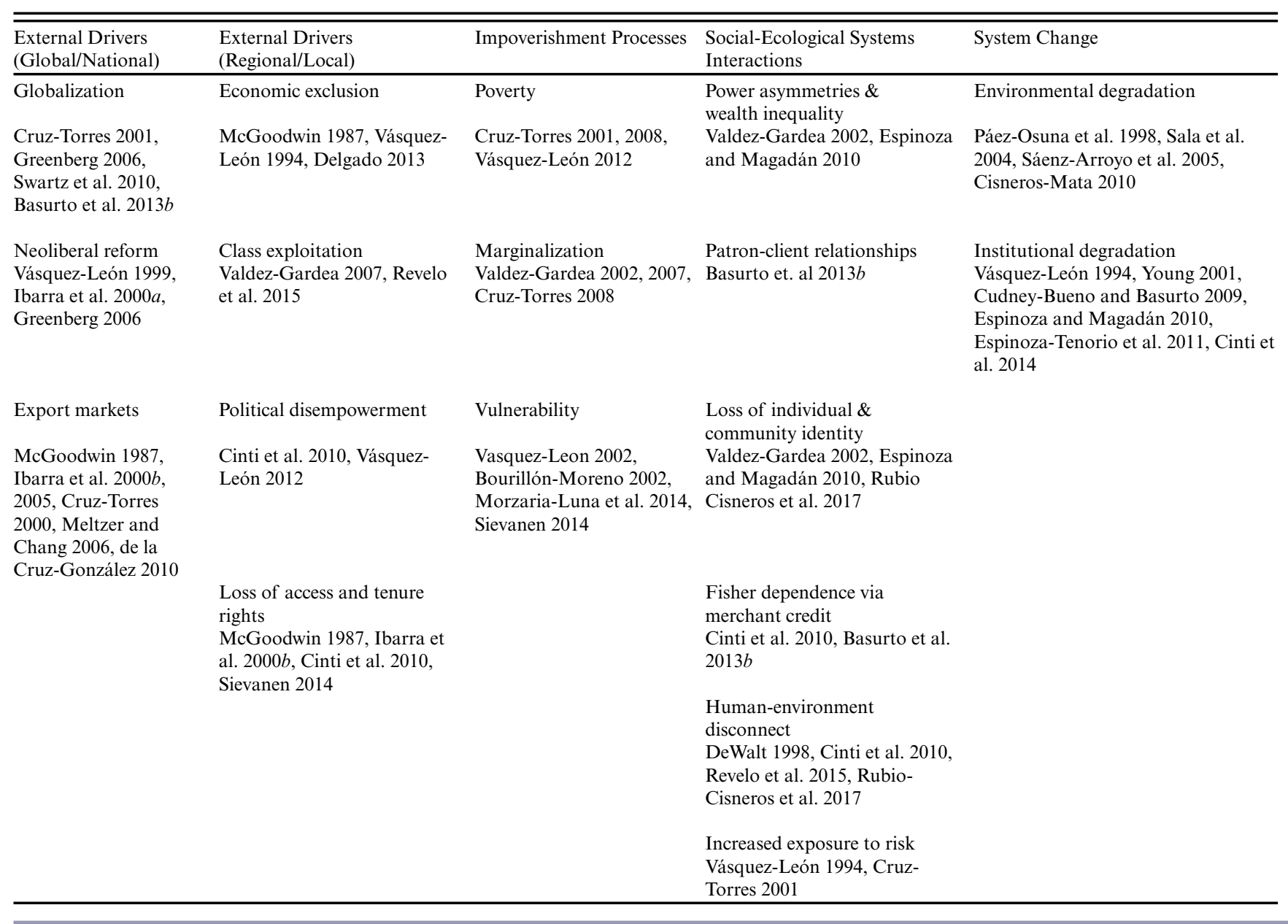

for small-scale producers, others have argued that these drivers lead to the polarization of communities by perpetuating existing inequalities, i.e., unequal access to wealth, political processes, land/sea tenure, education, and livelihoods, as only a few are able to reap the benefits while the majority remain poor (Bostock et al. 2004, Béné et al. 2010, Peterson 2015). According to their critics, neoliberalism and globalization represent nothing less than the colonization of nonmarket spheres of activity by the logic of commodity exchange (Castree 2010). As global actors reduce the autonomy of local communities, gradients of wealth and power inform the manner in which natural resources are appropriated, commodified, and transformed. Marine social science research often avoids or obscures how capitalist relations have interacted with inherited social, political, and economic structures to shape fisheries systems (Campling et al. 2012). Although early fisheries economists (Gordon 1954, Hardin 1968) did not use the term "neoliberal" when advancing private property rights and markets as solutions to overfishing, their seminal arguments are consistent with the neoliberal worldview. These classical arguments emphasizing individual economic rationality, upon which the preponderance of modern fisheries policies continue to be based, do not recognize the cultural, historical, and social characteristics of coastal fishing communities and cannot accommodate power relationships, economic inequality and exclusion, or class-based exploitation (St. Martin 2007, Davis and Ruddle 2012). Assuming that private property relations will appropriately distribute resources according to a single efficiency maximizing equation treats capital as a thing rather than examining the diverse social relations that constitute it (Durrenberger 1997, Peterson 2014).

If neoliberal ideologies have influenced and/or directed recent global processes, and such processes are socially and spatially uneven, then conceptual theories that provide a way to ground neoliberalism comparatively and analytically are of great value (Martin 2005). In the Gulf of California, global drivers have interacted with local and regional change processes to transform small-scale fisheries and the social-ecological systems in which they are embedded (Table 1). Neoliberal reforms have significantly increased the quantity and value of fisheries exports across the Gulf of California. But by allowing private entrepreneurs to access many of the fisheries historically reserved for cooperatives, they have incentivized overcapitalization and overfishing (Ibarra et al. 2000a). In addition, they have fostered a disparate organizational structure that has undermined the traditional practices and social relationships associated with 
sustainable harvest strategies and effective self-organization. We suggest that such processes are not unique. Below we synthesize recent literature documenting similar dynamics across other postcolonial states and advance a theoretical model of small-scale fisheries interactions in the age of globalization, linking drivers operating on multiple temporal and geographic scales with socialecological outcomes and system change.

\section{Unifying theoretical model}

Though the conventional wisdom on poverty in fisheries suggests that it is related to the low levels of natural resources resulting from overexploitation, the development literature has challenged neoclassical economic scholars to consider the economic, social, and cultural factors contributing to the institutional dynamics of poverty (Allison and Ellis 2001, Béné 2003). Such research asserts that vulnerability and marginalization are key concepts in understanding impoverishment processes within small-scale fishing communities and suggests economic exclusion, political disempowerment, loss of access and tenure rights, and class exploitation as key mechanisms that link these processes and accelerate poverty (Béné 2003, Allison and Horemans 2006, Béné and Friend 2011). Without property rights, fishermen are increasingly dependent upon patrons, middlemen, or brokers who are able to consolidate permits and equipment, channel global markets, and dictate the terms of exchange, issuing interest-free cash advances in exchange for increased rates of commission and the ability to fix the market price (Crona et al. 2010). Neoliberal privatization approaches that exacerbate wealth inequality and social division can lead to the degradation of public goods as selfserving owners with political power/influence become preoccupied with property rights and the maintenance of privileges attached to social status (Phillips et al. 2002). Fisheries patrons tend to invest in symbolic capital within the larger society rather than within the fishing community itself (Van Mulekom et al. 2006). Through accumulation by dispossession (Harvey 2004) many local elites have subordinated the ideals of neoliberal ideology for personal profit and political gain (Schultz 2017) at the expense of the livelihoods and well-being of coastal fishing communities. Market regulations and exchange transactions reduce the strength of traditional rules and sanctions, guaranteeing intermediaries a higher level of production and reducing cooperation and collective action to the point where traditional relationships of social control are no longer sustainable (Bennett 2017).

Poor, resource-dependent groups are thought to be the most vulnerable to the uncertainty associated with political shocks and environmental change (Adger et al. 2006). During periods of resource scarcity, fishers' may become trapped in a cycle of indebtedness that may result in the equivalent of bonded labor (Platteau and Abraham 1987, Nayak and Berkes 2011). As individuals are marginalized, they become disconnected from their environment and from one another (Neis et al. 2005, Fabinyi et al. 2015, Nayak et al. 2014). Patron-client relationships often generate incentives to extract certain species (Kininmonth et al. 2016) and may facilitate the recruitment of nonlocal labor (Fraga et al. 2008). Gradual social and economic alienation by resource users from fluctuations in the resource base often results in a loss of knowledge concerning how to respond to these fluctuations to secure future sustainable use (Crona et al. 2010) as illegal and destructive fishing practices become commonplace (Cinner 2009,
Jentoft et al. 2010). Many communities experience out-migration of traditional fishermen, and those that immigrate to take their place lack the environmental knowledge and sense of stewardship that facilitated the regulation of regional resource use (Berkes et al. 2006, Nayak and Berkes 2014). In summary (Fig. 2), we argue that global market forces driving self-governance arrangements where access rights and equipment are consolidated by individuals not actively engaged in the harvest represent a social-ecological trap that increases the level of poverty in coastal communities and accelerates the degradation of local resources and institutions.

\section{Agency and resistance}

Varying combinations of coercion, consent, contestation, and compromise describe the spatio-temporal evolution of neoliberal projects in different parts of the world (Castree 2010) and local manifestations of neoliberalism are always embedded in particular historical and geographic contexts. Although we suggest that the processes of neoliberal reform and globalization threaten the structure and functioning of marine social-ecological systems, such outcomes are by no means inevitable. Indeed, the tensions that generate social differentiation within societies and fisheries systems can lead to new forms of social organization and resistance (Campling et al. 2012). Across the globe, diverse coalitions of people are increasingly organizing around principles related to territory, ethnicity, decentralization, traditional knowledge, and self-determination to reject the hegemony of neoliberal control (Young 2001, Escobar 2008). Though we consider neoliberal discourse to be one of the dominant drivers of change in modern fishery systems, examples exist where it has been bypassed by alternatives and/or driven into retreat (Pinkerton 2017). Even under conditions of neoliberal globalization, local places play an important role in structuring the context of politics and political action (Martin 2005). As such, productive insight can be drawn from geographies where communities have united around the defense of livelihoods and resources threatened by dispossession.

In spite of attempts to separate local and/or indigenous peoples from their resources, the persistence of strong local governance institutions and customary legal systems have enabled a limited number of coastal communities in other parts of Mexico to resist the privatization of historical fishing grounds. The most frequently studied cases concern the well-organized community cooperatives of Baja Sur's Vizcaino region and Punta Allen of the Yucatan Peninsula (McCay et al. 2014, Méndez-Medina et al. 2015, Bennett 2017). In both regions resource users have leveraged collective access rights to enhance their bargaining power and successfully integrate with global markets. Although patronclient relationships are ubiquitous in areas characterized by high immigration rates, low barriers to entry, and weak norms of trust and reciprocity (Basurto et al. 2013), these examples of successful and enduring community cooperatives come from comparatively isolated regions. Throughout their respective histories, repeated exposures to natural perturbations, i.e., hurricanes, have forced inhabitants to rely upon one another and develop strong norms of cooperative behavior (McCay et al. 2014, Méndez-Medina et al. 2015). Remote fishing grounds, high levels of internal organization, and external support from NGOs and academic organizations have enabled resource users to secure coastal livelihoods without compromising traditional values and social 
Fig. 2. Theoretical model depicting small-scale fisheries interactions in the age of globalization. In the absence of alternatives, cross-scale interactions initiated by neoliberal reforms may represent a social-ecological trap that undermines institutional and environmental integrity.

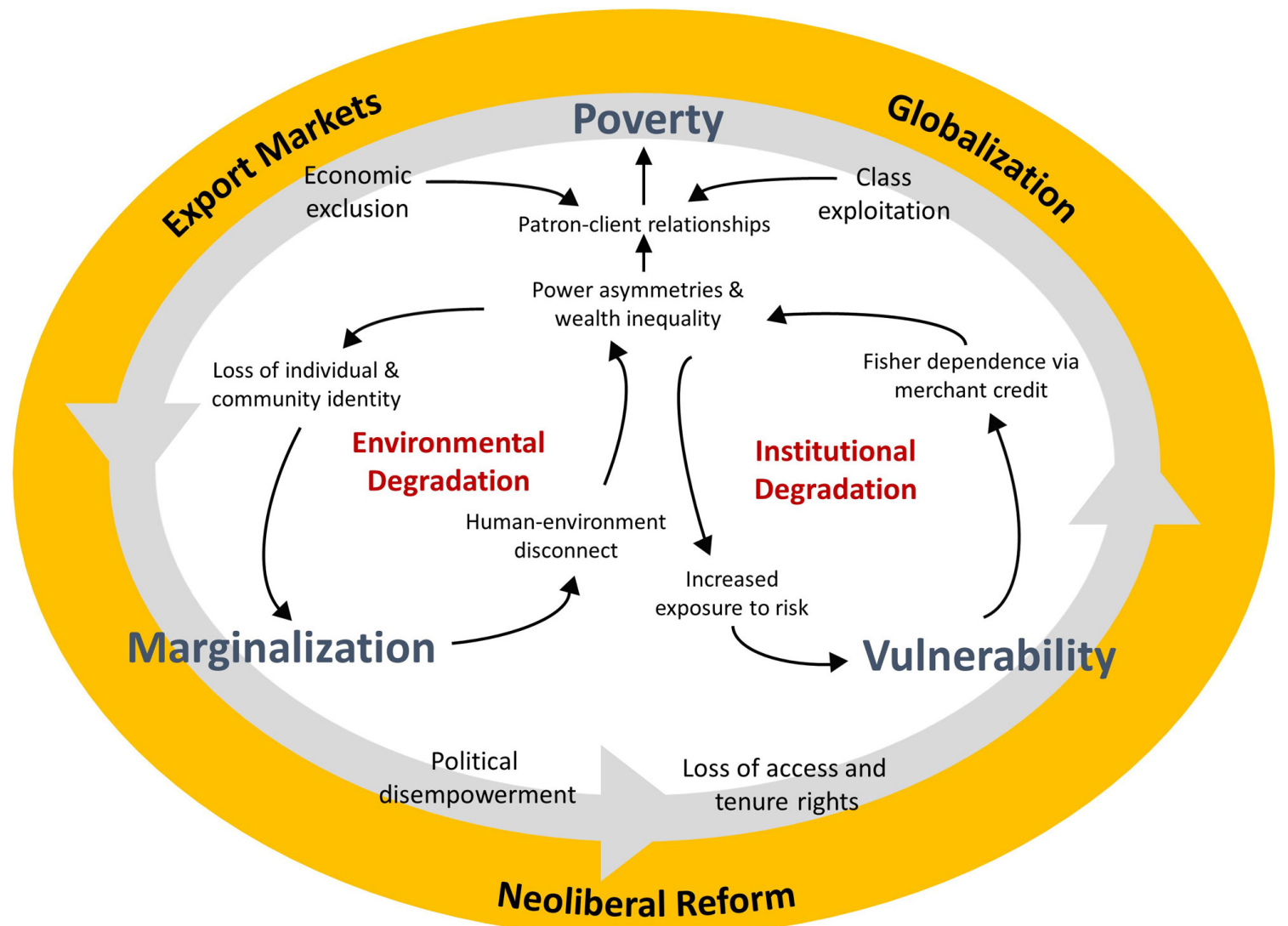

relationships. Building on the successful tradition of coastal ejidos (communal farm lands), cooperatives in both regions obtained renewable and exclusive 20-year concessions for the harvest of high-value, benthic species, i.e., lobster and/or abalone. Through processes of exclusion, negotiations to resolve stakeholder differences, and legitimacy derived from participation in scientific management and the cocreation of regulatory standards, these cooperatives have productively engaged with available governance and market mechanisms, integrating them with existing social norms and rules-in-use to defend access rights and capture resource revenues (Defeo and Castilla 2005, McCay et al. 2014, Méndez-Medina et al. 2015).

Though many of the factors linked with the positive, equitable, and sustainable social-ecological outcomes referenced above are context-dependent and/or biogeographically explicit, we advance human agency as a core concept. In Mexico (Weaver et al. 2012) and across the globe (Pinkerton 2017), the capacity to resist, withstand, or adapt to external forces like neoliberalism is increasingly linked with the ability of individuals, cultures, and communities to actively shape their own futures by establishing goals and pursuing objectives that they themselves deem worthwhile (Brown and Westaway 2011, Coulthard 2012, Cinner et al. 2018). Indeed, critical theorists have argued that human agency is one of the characteristics that distinguishes social systems from their ecological counterparts and, as such, is as an essential "additional conceptual layer" required to enhance our understanding of the conditions supporting resilience (Davidson 2010:1142, Cote and Nightingale 2012).

\section{DISCUSSION AND CONCLUSIONS}

As anthropologist James B. Greenberg (2006:129) asserts, the real tragedy "is "not of the commons but a tragedy of commoditization," when natural resources are managed as goods to be bought and sold without appreciation for their ecological function and social value. When global actors limit the accountability and control of local communities, policies that reduce social cohesion, reinforce existing power dynamics, and perpetuate economic inequality will likely lead to adverse human and environmental impacts (Durham 1995). Though our analysis concerns small-scale fisheries privatization and global market integration, similar patterns and processes have been identified amongst scholars examining the impacts of sustainable development projects (Weaver et al. 2012, Peterson 2015), fair trade agreements (Fridell 2006), ecotourism (Young 1999), and biodiversity conservation (Adams and Hutton 2007, AvilaForcada et al. 2012, Bennett et al. 2015) in the Gulf of California and elsewhere as the debate surrounding neoliberal reform, elite capture, and environmental sustainability continues across sectors, scales, and geographies. 
Table 2. Policy levers (across relevant levels of organization) for improving the structure and function of modern small-scale fishery systems.

\begin{tabular}{|c|c|c|}
\hline Level & Lever & Citations \\
\hline \multirow[t]{2}{*}{ Global } & Recognition of the social and cultural value of fisheries & Allison et al. 2012, Kittinger et al. 2017 \\
\hline & $\begin{array}{l}\text { Trade policy to support equitable and transparent supply chains and address } \\
\text { biosecurity concerns }\end{array}$ & Van Mulekom et al. 2006, McCauley et al. 2018 \\
\hline \multirow[t]{3}{*}{ National } & Redistribution of profits from export-oriented seafood trade & Béné et al. 2010, Bjørndal et al. 2015 \\
\hline & $\begin{array}{l}\text { Development of national markets and support for intra-regional trade } \\
\text { networks }\end{array}$ & Béné et al. 2010 \\
\hline & Institutional support for fishing cooperatives and federations & Jentoft 1989, 2005, Pomeroy and Berkes 1997 \\
\hline \multirow[t]{4}{*}{ Regional } & Development of management strategies sensitive to local rules-in-use & $\begin{array}{l}\text { Berkes et al. 2000, McClanahan et al. 2009, Cinti et al. } \\
2014\end{array}$ \\
\hline & Democratic empowerment of resource users & Jentoft 2005, Finkbeiner and Basurto 2015 \\
\hline & Labor organization movements & Campling et al. 2012 \\
\hline & Alternative marketing strategies and licensing regimes & $\begin{array}{l}\text { Levy 2010, McClenachan et al. 2014, Witter and Stoll } \\
2017\end{array}$ \\
\hline \multirow[t]{2}{*}{ Local } & Assertion of local and/or indigenous fishing and conservation rights & Johannes 2002, Jones et al. 2017 \\
\hline & Social movements to protect fish habitat & Altamirano-Jiménez 2017 \\
\hline
\end{tabular}

With the field of social-ecological systems becoming increasingly influential across international policy arenas it is important to challenge many of its normative assumptions about human behavior and systems organization (Cote and Nightingale 2012, Fabyini et al. 2014). In practice, decision-making processes and practices are not products of consensus and homogeneity, but rather are shaped by the tensions between classes, economies, and political systems. Although researchers have made considerable progress expanding the scope of their analyses (Armitage and Johnson 2006, Young et al. 2006, Janssen et al. 2007), additional efforts are required to elevate the significance of such findings beyond theoretical discourse. By examining the links between global, regional, and local change processes and merging diverse literatures, we hope to advance common pool resource theory and increase the relevance of its findings. Although neoclassical fisheries economists and modern SES scholars agree that the tragedy of the commons cannot be avoided without secure access and tenure rights, we argue that resource rights may serve only to exacerbate the problem if an "entitlement failure" occurs (Béné 2003, Mansfield 2011). When the benefits of market integration and privatization are unevenly distributed and/or captured by elites, increasing social and economic inequality will leave active resource users with little incentive or opportunity to self-regulate. Though the magnitude and direction of these linkages is likely to vary across geographies and study systems, by generalizing our findings we hope to provide a theoretical model that can be dissected, tested, and improved by a diverse audience of scholars and practitioners.

Following the global financial crisis of 2008, challenges to the neoliberal world order have intensified as opposition movements have grown in number, strength, and diversity. While acknowledging the limitations and dangers of populist discourses rooted in nationalist appeal, we support the need for alternative approaches to the management and governance of small-scale fisheries. Given that small-scale fisheries are now globally integrated, policy makers, resource managers, and fisheries practioners must address the existence of international trade networks and the social structures that have developed alongside them. Building on previous literature (Béné et al. 2010, Kittinger et al. 2017, Pinkerton 2017) we propose a suite of levers for more nuanced, tractable, and equitable fisheries policies that can be enacted across existing levels of organization (Table 2).

No single approach can solve problems emerging from globalization, but various approaches can be used in concert to mitigate the effects of roving bandits and replace destructive incentives with resource rights frameworks that promote environmental stewardship and "build the self-interested, conserving feedback that comes from attachment to place" (Berkes et al. 2006:1558). Effective national fisheries policies may have to be codeveloped with well-designed poverty and development projects in accordance with human rights protocols (Allison et al. 2012, Weeratunge et al. 2014, Kittinger et al. 2017) and incorporate strategies designed to restore the connections between resources and people by shifting existing power and market dynamics (Nayak et al. 2014). Though patron-client relationships are expected to be less conducive to conservation behaviors (Johnson 2010), the emergence of such relationships is expected to increase across the Gulf of California alongside coastal development and urbanization (Basurto et. al 2013b). Rather than focusing on the protection of flagship species, international conservation organizations working in the region should address the social issues dictating how coastal communities interact with the marine environment (CisernosMontemayor and Vincent 2016). Likewise, the scientific research community can play an important role in assessing the linkages between environmental sustainability and socioeconomic context, aggregating the expertise required to inform responses by businesses, government, nonprofits, and communities (Kittinger et al. 2017).

Stakeholder engagement and comanagement are crucial for successful environmental policy, often influencing outcomes more than the management schemes themselves (Gutiérrez et al. 2011). If fishers in the Gulf of California are to be deputized as the stewards of their target resources, their active participation in management decisions and in research and monitoring activities is critically important. As the spatial scale of resource use increases alongside the heterogeneity of resources and resource users (Berkes et al. 2006), traditional community-based 
management systems must evolve and adapt (Finkbeiner and Basurto 2015). Recognizing and accounting for regional heterogeneity in ecosystem structure and social organization may help to identify those strategies best suited for specific socialecological contexts. As effective as community-based management systems may be at local scales, it is likely that they will only last as long as the system remains buffered from external pressures (Cudney-Bueno and Basurto 2009). Though social and environmental change is inevitable as small-scale fisheries are integrated with global markets, multilevel governance structures can be designed to harness the benefits and ensure their equitable distribution (Crona et al. 2015). Although top-down control measures have a decidedly mixed track-record, it appears evident that the nation-state has a critical role to play in the management of small-scale fisheries through supporting the development and persistence of strong, local institutions.

Resource managers who seek to promote sustainable use and avoid the tragedy of the commons must recognize the importance of granting secure access and tenure rights to small-scale fishermen actively engaged in extractive behavior, while encouraging the diversification of their activities and marketing options. Moving forward, if we acknowledge that property rights are a societal construct and that property regimes can be tailored to accomplish specific objectives (Bromley and Feeny 1992), perhaps it is time to move beyond traditional notions of fishing "rights" and begin to reconsider how fishing privileges, contingent upon duties related to resource monitoring, stewardship, and governance, could be designed and implemented to foster sustainable use.

Responses to this article can be read online at: http://www.ecologyandsociety.org/issues/responses. $\mathrm{php} / 10693$

\section{Acknowledgments:}

The authors would like to thank Julia Mason and two anonymous reviewers for their valuable comments on an earlier version of the manuscript in addition to $C G$ and $L G$ for ongoing research and logistical support.

\section{LITERATURE CITED}

Acheson, J. M. 1985. The Maine lobster market: between market and hierarchy. Journal of Law, Economics, \& Organization 1 (2):385-398.

Adams, W. M., and J. Hutton. 2007. People, parks and poverty: political ecology and biodiversity conservation. Conservation and Society 5(2):147-183.

Adger, W. N., J. Paavola, and S. Huq. 2006. Toward justice in adaptation to climate change. Pages 1-19 in W. N. Adger, J. Paavola, S. Huq, and M. J. Mace, editors. Fairness in adaptation to climate change. MIT Press, Cambridge, Massachusetts, USA. http://dx.doi.org/10.7551/mitpress/2957.003.0004

Aguilera, S. E., J. Cole, E. M. Finkbeiner, E. Le Cornu, N. C. Ban, M. H. Carr, J. E. Cinner, L. B. Crowder, S. Gelcich, C. C. Hicks, J. N. Kittinger, R. Martone, D. Malone, C. Pomeroy, R. M. Starr,
S. Seram, R. Zuercher, and K. Broad. 2015. Managing small-scale commercial fisheries for adaptive capacity: insights from dynamic social-ecological drivers of change in Monterey Bay. PLoS ONE 10(3):e0118992.http://dx.doi.org/10.1371/journal.pone.0118992

Alder, J., and R. Watson, editors. 2007. Fisheries globalization: fair trade or piracy. Pages 47-74 in W. W. Taylor, M. G. Schechter, and L. G. Wolfson, editors. Globalization: effects on fisheries resources. Cambridge University Press, Cambridge, UK. http:// dx.doi.org/10.1017/CBO9780511542183.006

Allison, E. H., and F. Ellis. 2001. The livelihoods approach and management of small-scale fisheries. Marine Policy 25 (5):377-388. http://dx.doi.org/10.1016/S0308-597X(01)00023-9

Allison, E. H., and B. Horemans. 2006. Putting the principles of the sustainable livelihoods approach into fisheries development policy and practice. Marine Policy 30(6):757-766. http://dx.doi. org/10.1016/j.marpol.2006.02.001

Allison, E. H., B. D. Ratner, B. Åsgård, R. Willmann, R. Pomeroy, and J. Kurien. 2012. Rights-based fisheries governance: from fishing rights to human rights. Fish and Fisheries 13(1):14-29. http://dx.doi.org/10.1111/j.1467-2979.2011.00405.x

Altamirano-Jiménez, I. 2017. "The sea is our bread": interrupting green neoliberalism in Mexico. Marine Policy 80:28-34. http://dx. doi.org/10.1016/i.marpol.2017.01.015

Alverson, D. L., M. H. Freeberg, S. A. Murawski, and J. G. Pope. 1994. A global assessment of bycatch and discards. Food and Agricultural Organization (FAO) Technical Paper No. 339. FAO, Rome, Italy.

Amarasinghe, O. 1989. Technical change, transformation of risks and patronage relations in a fishing community of South Sri Lanka. Development and Change 20(4):701-733. http://dx.doi. org/10.1111/j.1467-7660.1989.tb00363.x

Anderson, J. M. 2003. The international seafood trade. Woodhead, Cambridge, UK.

Arenas-Fuentes, P., and A. D. de León-Corral. 1997. How to achieve sustainable fisheries development in a developing country: the case of México. Pages 586-592 in D. A. Hancock, D. C. Smith, A. Grant, and J. P. Beumer, editors. Developing and sustaining world fisheries resources. The state of science and management. Second World Fisheries Congress, CSIRO, Brisbane, Australia.

Armitage, D. R., and D. Johnson. 2006. Can resilience be reconciled with globalization and the increasingly complex conditions of resource degradation in Asian coastal regions? Ecology and Society 11(1):2. http://dx.doi.org/10.5751/ES-01485-110102

Avila-Forcada, S., A. L. Martínez-Cruz, and C. Muñoz-Piña. 2012. Conservation of vaquita marina in the northern Gulf of California. Marine Policy 36(3):613-622. http://dx.doi.org/10.1016/ j.marpol.2011.10.012

Basurto, X., A. Bennett, A. Hudson Weaver, S. Rodriguez-Van Dyck, and J.-S. Aceves-Bueno. 2013b. Cooperative and noncooperative strategies for small-scale fisheries' selfgovernance in the globalization era: implications for conservation. Ecology and Society 18(4):38. http://dx.doi. org/10.5751/ES-05673-180438 
Basurto, X., S. Gelcich, and E. Ostrom. 2013a. The socialecological system framework as a knowledge classificatory system for benthic small-scale fisheries. Global Environmental Change 23 (6):1366-1380. http://dx.doi.org/10.1016/j.gloenvcha.2013.08.001

Basurto, X., and E. Ostrom. 2009. Beyond the tragedy of the commons. Economia Delle Fonti di Energia e Dell'Ambiente 52 (1):35-60.

Béné, C. 2003. When fishery rhymes with poverty: a first step beyond the old paradigm on poverty in small-scale fisheries. World Development 31(6):949-975. http://dx.doi.org/10.1016/S0305-750X (03)00045-7

Béné, C., and R. M. Friend. 2011. Poverty in small-scale fisheries: old issue, new analysis. Progress in Development Studies 11 (2):119-144. http://dx.doi.org/10.1177/146499341001100203

Béné, C., R. Lawton, and E. H. Allison. 2010. "Trade matters in the fight against poverty": narratives, perceptions, and (lack of) evidence in the case of fish trade in Africa. World Development 38(7):933-954. http://dx.doi.org/10.1016/j.worlddev.2009.12.010

Béné, C., G. Macfadyen, and E. H. Allison. 2007. Increasing the contribution of small scale fisheries to poverty alleviation and food security. Food and Agriculture Organization (FAO) Fisheries Technical Paper No. 481. FAO, Rome, Italy.

Bennett, A. 2017. The influence of neoliberalization on the success and failure of fishing cooperatives in contemporary smallscale fishing communities: a case study from Yucatán, Mexico. Marine Policy 80:96-106. http://dx.doi.org/10.1016/j.marpol.2016.06.024

Bennett, A., and X. Basurto. 2018. Local institutional responses to global market pressures: the sea cucumber trade in Yucatán, Mexico. World Development 102:57-70. http://dx.doi.org/10.1016/ j.worlddev.2017.09.006

Bennett, N. J., H. Govan, and T. Satterfield. 2015. Ocean grabbing. Marine Policy 57:61-68. http://dx.doi.org/10.1016/j. marpol.2015.03.026

Berkes, F., J. Colding, and C. Folke. 2000. Rediscovery of traditional ecological knowledge as adaptive management. Ecological Applications 10(5):1251-1262. http://dx.doi. org/10.1890/1051-0761(2000)010[1251:ROTEKA]2.0.CO;2

Berkes, F., D. Feeny, B. J. McCay, and J. M. Acheson. 1989. The benefits of the commons. Nature 340:91-93. http://dx.doi. org/10.1038/340091a0

Berkes, F., C. Folke, and J. Colding, editors. 1998. Linking social and ecological systems: management practices and social mechanisms for building resilience. Cambridge University Press, Cambridge, UK.

Berkes, F., T. P. Hughes, R. S. Steneck, J. A. Wilson, D. R. Bellwood, B. Crona, C. Folke, L. H. Gunderson, H. M. Leslie, J. Norberg, M. Nyström, P. Olsson, H. Österblom, M. Scheffer, and B. Worm. 2006. Globalization, roving bandits, and marine resources. Science 311:1557-1558. http://dx.doi.org/10.1126/ science. 1122804

Berkes, F., R. Mahon, P. McConney, R. C. Pollnac, and R. S. Pomeroy. 2001. Managing small-scale fisheries: alternative directions and methods. International Development Research Centre, Ottawa, Ontario, Canada.
Bjørndal, T., A. Child, A. Lem, and M. M. Dey. 2015. Value chain dynamics and the small-scale sector: a summary of findings and policy recommendations for fisheries and aquaculture trade. Aquaculture Economics \& Management 19(1):148-173. http://dx. doi.org/10.1080/13657305.2015.994241

Bostock, T., P. Greenhalgh, and U. Kleih. 2004. Policy researchimplications of liberalisation of fish trade for developing countries. Natural Resources Institute, Chatham, UK.

Bourillón-Moreno, L. 2002. Exclusive fishing zone as a strategy for managing fishery resources by the Seri Indians, Gulf of California, Mexico. Dissertation. The University of Arizona, Tucson, Arizona, USA.

Brenner, N., J. Peck, and N. Theodore. 2010. Variegated neoliberalization: geographies, modalities, pathways. Global Networks 10(2):182-222. http://dx.doi.org/10.1111/j.1471-0374.2009.00277. $\underline{\mathrm{x}}$

Breunig, L. A. 2006. Conservation in context: establishing natural protected areas during Mexico's neoliberal reformation. Dissertation. The University of Arizona, Tucson, Arizona, USA.

Bromley, D. W., and D. Feeny, editors. 1992. Making the commons work: theory, practice, and policy. ICS, San Francisco, California, USA.

Brown, K., and E. Westaway. 2011. Agency, capacity, and resilience to environmental change: lessons from human development, well-being, and disasters. Annual Review of Environment and Resources 36:321-342. http://dx.doi.org/10.1146/ annurev-environ-052610-092905

Campling, L., E. Havice, and P. McCall Howard. 2012. The political economy and ecology of capture fisheries: market dynamics, resource access and relations of exploitation and resistance. Journal of Agrarian Change 12(2-3):177-203. http://dx. doi.org/10.1111/j.1471-0366.2011.00356.x

Carothers, C., and C. Chambers. 2012. Fisheries privatization and the remaking of fishery systems. Environment and Society 9 (1):39-59. http://dx.doi.org/10.3167/ares.2012.030104

Carvajal, M. A., E. Ezcurra, and A. Robles. 2004. The Gulf of California: natural resource concerns and the pursuit of a vision. Pages 105-124 in L. K. Glover and S. A. Earl, editors. Defying ocean's end: an agenda for action. Island, Washington, D.C., USA.

Castree, N. 2008a. Neoliberalising nature: the logics of deregulation and reregulation. Environment and Planning A 40 (1):131-152. http://dx.doi.org/10.1068/a3999

Castree, N. 2008b. Neoliberalising nature: processes, effects, and evaluations. Environment and Planning A 40(1):153-173. http://dx. doi.org/10.1068/a39100

Castree, N. 2010. Neoliberalism and the biophysical environment: a synthesis and evaluation of the research. Environment and Society 1(1):5-45. http://dx.doi.org/10.3167/ares.2010.010102

Chuenpagdee, R., editor. 2011. World small-scale fisheries: contemporary visions. Eburon, Delft, the Netherlands.

Cinner, J. E. 2009. Poverty and the use of destructive fishing gear near east African marine protected areas. Environmental Conservation 36(4):321-326. http://dx.doi.org/10.1017/ $\underline{\mathrm{S} 0376892910000123}$ 
Cinner, J. E., W. N. Adger, E. H. Allison, M. L. Barnes, K. Brown, P. J. Cohen, S. Gelcich, C. C. Hicks, T. P. Hughes, J. Lau, N. A. Marshall, and T. H. Morrison. 2018. Building adaptive capacity to climate change in tropical coastal communities. Nature Climate Change 8:117-123. http://dx.doi.org/10.1038/s41558-017-0065-x

Cinner, J. E., T. R. McClanahan, T. M. Daw, N. A. J. Graham, J. Maina, S. K. Wilson, and T. P. Hughes. 2009. Linking social and ecological systems to sustain coral reef fisheries. Current Biology 19(3):206-212. http://dx.doi.org/10.1016/j.cub.2008.11.055

Cinti, A., J. N. Duberstein, E. Torreblanca, and M. Moreno-Báez. 2014. Overfishing drivers and opportunities for recovery in smallscale fisheries of the Midriff Islands Region, Gulf of California, Mexico: the roles of land and sea institutions in fisheries sustainability. Ecology and Society 19(1):15. http://dx.doi. org/10.5751/ES-05570-190115

Cinti, A., W. Shaw, R. Cudney-Bueno, and M. Rojo. 2010. The unintended consequences of formal fisheries policies: social disparities and resource overuse in a major fishing community in the Gulf of California, Mexico. Marine Policy 34:328-339. http:// dx.doi.org/10.1016/j.marpol.2009.08.002

Cisneros-Mata, M. A. 2010. The importance of fisheries in the Gulf of California and ecosystem-based sustainable comanagement for conservation. Pages 119-134 in R. Brusca, editor. The Gulf of California: biodiversity and conservation. ArizonaSonora Desert Museum Studies in Natural History, The University of Arizona Press, Tucson, Arizona, USA.

Cisneros-Montemayor, A. M., M. A. Cisneros-Mata, S. Harper, and D. Pauly. 2013. Extent and implications of IUU catch in Mexico's marine fisheries. Marine Policy 39:283-288. http://dx. doi.org/10.1016/j.marpol.2012.12.003

Cisneros-Montemayor, A. M., and A. Vincent. 2016. Science, society, and flagship species: social and political history as keys to conservation outcomes in the Gulf of California. Ecology and Society 21(2):9. http://dx.doi.org/10.5751/ES-08255-210209

Costello, C., S. D. Gaines, and J. Lynham. 2008. Can catch shares prevent fisheries collapse? Science 321:1678-1681. http://dx.doi. org/10.1126/science. 1159478

Cote, M., and A. J. Nightingale. 2012. Resilience thinking meets social theory: situating social change in socio-ecological systems (SES) research. Progress in Human Geography 36(4):475-489. http://dx.doi.org/10.1177/0309132511425708

Coulthard, S. 2012. Can we be both resilient and well, and what choices do people have? Incorporating agency into the resilience debate from a fisheries perspective. Ecology and Society 17(1):4. http://dx.doi.org/10.5751/ES-04483-170104

Crona, B., X. Basurto, D. Squires, S. Gelcich, T. M. Daw, A. Khan, E. Havice, V. Chomo, M. Troell, E. A. Buchar, and E. H. Allison. 2016. Towards a typology of interactions between small-scale fisheries and global seafood trade. Marine Policy 65:1-10. http:// dx.doi.org/10.1016/j.marpol.2015.11.016

Crona, B., and Ö. Bodin. 2010. Power asymmetries in small-scale fisheries: a barrier to governance transformability? Ecology and Society 15(4):32. http://dx.doi.org/10.5751/ES-03710-150432

Crona, B., M. Nyström, C. Folke, and N. Jiddawi. 2010. Middlemen, a critical social-ecological link in coastal communities of Kenya and Zanzibar. Marine Policy 34 (4):761-777. http://dx.doi.org/10.1016/j.marpol.2010.01.023

Crona, B. I., T. Van Holt, M. Petersson, T. M. Daw, and E. Buchary. 2015. Using social-ecological syndromes to understand impacts of international seafood trade on small-scale fisheries. Global Environmental Change 35:162-175. http://dx.doi. org/10.1016/j.gloenvcha.2015.07.006

Cruz-Torres, M. L. 2000. "Pink Gold Rush": shrimp aquaculture, sustainable development, and the environment in northwestern Mexico. Journal of Political Ecology: Case Studies in History and Society 7(1):63-90. http://dx.doi.org/10.2458/v7i1.21547

Cruz-Torres, M. L. 2001. Local-level responses to environmental degradation in northwestern Mexico. Journal of Anthropological Research 57(2):111-136. http://dx.doi.org/10.1086/jar.57.2.3631563

Cruz-Torres, M. L. 2008. Lives of dust and water: an anthropology of change and resistance in Northwestern Mexico. University of Arizona Press, Tucson, Arizona, USA.

Cudney-Bueno, R., and X. Basurto. 2009. Lack of cross-scale linkages reduces robustness of community-based fisheries management. PLoS ONE 4(7):e6253. http://dx.doi.org/10.1371/ journal.pone.0006253

Davidson, D. J. 2010. The applicability of the concept of resilience to social systems: some sources of optimism and nagging doubts. Society and Natural Resources 23:1135-1149. http://dx.doi. org/10.1080/08941921003652940

Davis, A., and K. Ruddle. 2012. Massaging the misery: recent approaches to fisheries governance and the betrayal of small-scale fisheries. Human Organization 71(3):244-254. http://dx.doi. org/10.17730/humo.71.3.205788362x751128

de la Cruz-González, F. J., L. F. Beltrán-Morales, C. A. SalinasZavala, M. Á. Cisneros-Mata, E. A. Aragón-Noriega, and G. Avilés-Polanco. 2011. Análisis socioeconómico de la pesquería de calamar gigante en Guaymas, Sonora. Economía, Sociedad y Territorio 11(37):645-666. http://dx.doi.org/10.22136/est00201199

Defeo, O., and J. C. Castilla. 2005. More than one bag for the world fishery crisis and keys for co-management successes in selected artisanal Latin American shellfisheries. Reviews in Fish Biology and Fisheries 15(3):265-283. http://dx.doi.org/10.1007/ s11160-005-4865-0

Delgado, C. 2013. La pesca ribereña en el contexto económico capitalista. Apuntes sobre una propuesta de análisis. Pages 203-1221 in G. C. Valdéz, M. S. Gardea, and B. Galindo, editors. Pesquerías globalizadas. El Colegio de Sonora y Universidad Autónoma de Baja California, Hermosillo, Mexico.

DeWalt, B. R. 1998. The Ejido reforms and Mexican coastal communities: fomenting a blue revolution. Pages 357-379 in W. A. Cornelius and D. Myhre, editors. The transformation of rural Mexico, reforming the Ejido. Center of United States-Mexico Studies at the University of California, San Diego, La Jolla, California, USA.

Durham, W. H., 1995. Political ecology and environmental destruction in Latin America. Pages 249-379 in M. Painter and W. H. Durham, editors. The social causes of environmental destruction in Latin America. University of Michigan Press, Ann Arbor, Michigan, USA. 
Durrenberger, E. P. 1997. Fisheries management models: assumptions and realities or, why shrimpers in Mississippi are not firms. Human Organization 56:158-166. http://dx.doi.org/10.17730/ humo.56.2.k1t2731314r8x2w1

Escobar, A. 2008. Territories of difference: place, movements, life, redes. Duke University Press, Durham, North Carolina, USA. http://dx.doi.org/10.1215/9780822389439

Espinoza, B., and R. Magadán. 2010. Cooperativismo pesquero en la comunidad la reforma Sinaloa, caso de la pesca artesanal. Dissertation. Universidad Autónoma Chapingo, Chapingo, México.

Espinoza-Tenorio, A., I. Espejel, M. Wolf, and J. A. ZepedaDomínguez. 2011. Contextual factors influencing sustainable fisheries in Mexico. Marine Policy 35:343-350. http://dx.doi. org/10.1016/j.marpol.2010.10.014

Fabinyi, M., L. Evans, and S. J. Foale. 2014. Social-ecological systems, social diversity, and power: insights from anthropology and political ecology. Ecology and Society 19(4):28. http://dx.doi. org/10.5751/ES-07029-190428

Fabinyi, M., S. Foale, and M. Macintyre. 2015. Managing inequality or managing stocks? An ethnographic perspective on the governance of small-scale fisheries. Fish and Fisheries 16 (3):471-485. http://dx.doi.org/10.1111/faf.12069

Farr, E. R., J. S. Stoll, and C. M. Beitl. 2018. Effects of fisheries management on local ecological knowledge. Ecology and Society 23(3):15. http://dx.doi.org/10.5751/ES-10344-230315

Feeny, D., F. Berkes, B. J. McCay, and J. M. Acheson. 1990. The tragedy of the commons: twenty-two years later. Human Ecology 18(1):1-19. http://dx.doi.org/10.1007/BF00889070

Finkbeiner, E. 2014. Survival and sustainability in small-scale Mexican fisheries: a cross-scale examination of resilience in marine social-ecological system. Dissertation. Stanford University, Stanford, California, USA.

Finkbeiner, E. M. 2015. The role of diversification in dynamic small-scale fisheries: lessons from Baja California Sur, Mexico. Global Environmental Change 32:139-152. http://dx.doi. org/10.1016/j.gloenvcha.2015.03.009

Finkbeiner, E. M., and X. Basurto. 2015. Re-defining comanagement to facilitate small-scale fisheries reform: an illustration from northwest Mexico. Marine Policy 51:433-441. http://dx.doi.org/10.1016/j.marpol.2014.10.010

Finkbeiner, E. M., N. J. Bennett, T. H. Frawley, J. G. Mason, D. K. Briscoe, C. M. Brooks, C. A. Ng, R. Ourens, K. Seto, S. Switzer Swanson, J. Urteaga, and L. B. Crowder. 2017. Reconstructing overfishing: moving beyond Malthus for effective and equitable solutions. Fish and Fisheries 18(6):1180-1191. http://dx.doi. org/10.1111/faf.12245

Fraga, J., S. Salas, and G. Mexicano. 2008. La pesca en Yucatán: de la abundancia a la escasez, a la fragilidad de las estructuras institucionales. Pages 133-148 in J. Fraga, G. J. Villalobos, S. Doyon, and A. Garcia, editors. Descentralización y manejo ambiental. Gobernanza costera en México. Plaza y Valdés (IDRC), Campeche, México.
Fridell, G. 2006. Fair trade and neoliberalism: assessing emerging perspectives. Latin American Perspectives 33(6):8-28. http://dx. doi.org/10.1177/0094582X06294109

Gordon, H. S. 1954. The economic theory of a common-property resource: the fishery. Journal of Political Economy 62(2):124-142.

Greenberg, J. B. 2006. The political ecology of fisheries in the Upper Gulf of California. Pages 121-148 in A. Biersack and J. B. Greenberg, editors. Reimagining political ecology. Duke University Press, Durham, North Carolina, USA. http://dx.doi. org/10.1215/9780822388142-005

Greenberg, J. B., T. Weaver, A. Browning-Aiken, and W. L. Alexander. 2012. The neoliberal transformation of Mexico. Pages 1-32 in T. Weaver, J. B. Greenberg, W. L. Alexander, and A. Browning, editors. Neoliberalism and commodity production in Mexico. University Press of Colorado, Boulder, Colorado, USA.

Gutiérrez, N. L., R. Hilborn, and O. Defeo. 2011. Leadership, social capital and incentives promote successful fisheries. Nature 470:386-389. http://dx.doi.org/10.1038/nature09689

Hardin, G. 1968. The tragedy of the commons. Science 162:1243-1248. http://dx.doi.org/10.1126/science.162.3859.1243

Harvey, D. 2004. The 'new' imperialism: accumulation by dispossession. Socialist Register 40(40).

Hilborn, R., J.-J. Maguire, A. M. Parma, and A. A. Rosenberg. 2001. The precautionary approach and risk management: can they increase the probability of successes in fishery management? Canadian Journal of Fisheries and Aquatic Sciences 58(1):99-107. http://dx.doi.org/10.1139/f00-225

Ibarra, A. A. 2017. The forgone benefits of discarding fish in the Gulf of California shrimp fishery. Ocean \& Coastal Management 145:1-13. http://dx.doi.org/10.1016/j.ocecoaman.2017.04.011

Ibarra, A. A., A. Peña, and J. González-Cano. 2005. Biodiversity conservation against an export-led industry: fisheries development in Mexico. Aquatic Resources, Culture and Development 1(1):119-129.

Ibarra, A. A., and G. Ramírez Soberón. 2002. Economic reasons, ecological actions and social consequences in the Mexican sea cucumber fishery. SPC Beche-de-Mer Information Bulletin $17: 33-26$

Ibarra, A. A., C. Reid, and A. Thorpe. 2000a. The political economy of marine fisheries development in Peru, Chile and Mexico. Journal of Latin American Studies 32(2):503-527. http:// dx.doi.org/10.1017/S0022216X00005824

Ibarra, A. A., C. Reid, and A. Thorpe. 2000b. Neo-liberalism and its impact on overfishing and overcapitalisation in the marine fisheries of Chile, Mexico and Peru. Food Policy 25(5):599-622. http://dx.doi.org/10.1016/S0306-9192(00)00014-2

Janssen, M. A., J. M. Anderies, and E. Ostrom. 2007. Robustness of social-ecological systems to spatial and temporal variability. Society and Natural Resources 20(4):307-322. http://dx.doi. org/10.1080/08941920601161320

Jentoft, S. 1989. Fisheries co-management: delegating government responsibility to fishermen's organizations. Marine Policy 13(2):137-154. http://dx.doi.org/10.1016/0308-597X(89) 90004-3 
Jentoft, S. 2005. Fisheries co-management as empowerment. Marine Policy 29(1):1-7. http://dx.doi.org/10.1016/j.marpol.2004.01.003

Jentoft, S., P. Onyango, and M. M. Islam. 2010. Freedom and poverty in the fishery commons. International Journal of the Commons 4(1):345-36. http://dx.doi.org/10.18352/ijc.157

Johannes, R. E. 2002. The renaissance of community-based marine resource management in Oceania. Annual Review of Ecology and Systematics 33(1):317-340. http://dx.doi.org/10.1146/ annurev.ecolsys.33.010802.150524

Johnson, D. S. 2010. Institutional adaptation as a governability problem in fisheries: patron-client relations in the Junagadh fishery, India. Fish and Fisheries 11(3):264-277. http://dx.doi. org/10.1111/j.1467-2979.2010.00376.X

Jones, R., C. Rigg, and E. Pinkerton. 2017. Strategies for assertion of conservation and local management rights: a Haida Gwaii herring story. Marine Policy 80:154-167. http://dx.doi. org/10.1016/j.marpol.2016.09.031

Kininmonth, S., B. Crona, Ö Bodin, I. Vaccaro, L. J. Chapman, and C. A. Chapman. 2016. Microeconomic relationships between and among fishers and traders influence the ability to respond to social-ecological changes in a small-scale fishery. Ecology and Society 22(2):26. http://dx.doi.org/10.5751/ES-08833-220226

Kittinger, J. N., E. M. Finkbeiner, N. C. Ban, K. Broad, M. H. Carr, J. E. Cinner, S. Gelcich, M. L. Cornwell, J. Z. Koehn, X. Basurto, R. Fujita, M. R. Caldwell, and L. B. Crowder. 2013. Emerging frontiers in social-ecological systems research for sustainability of small-scale fisheries. Current Opinion in Environmental Sustainability 5:352-357. http://dx.doi.org/10.1016/ j.cosust.2013.06.008

Kittinger, J. N., L. C. L. Teh, E. H. Allison, N. J. Bennett, L. B. Crowder, E. M. Finkbeiner, C. Hicks, C. G. Scarton, K. Nakamura, Y. Ota, J. Young, A. Alifano, A. Apel, A. Arbib, L. Bishop, M. Boyle, A. M. Cisneros-Montemayor, P. Hunter, E. L. Cornu, M. Levine, R. S. Jones, J. Z. Koehn, M. Marschke, J. G. Mason, F. Micheli, L. McClenachan, C. Opal, J. Peacy, S. H. Peckham, E. Schemmel, V. Solis-Rivera, W. Swartz, and T. Aulani Wilhelm. 2017. Committing to socially responsible seafood. Science 356(6341):912-913. http://dx.doi.org/10.1126/science. $\underline{\text { aam9969 }}$

Larner, W. 2000. Neo-liberalism: policy, ideology, governmentality. Studies in Political Economy 63(1):5-25. http://dx.doi. org/10.1080/19187033.2000.11675231

Leslie, H. M., X. Basurto, M. Nenadovic, L. Sievanen, K. C. Cavanaugh, J. J. Cota-Nieto, B. E. Erisman, E. M. Finkbeiner, G. Hinojosa-Arango, M. Moreno-Báez, S. Nagavarapu, S. M. W. Reddy, A. Sánchez-Rodríguez, K. Siegel, J. J. UlibarriaValenzuela, A. H. Weaver, and O. Aburto-Oropeza. 2015. Operationalizing the social-ecological systems framework to assess sustainability. Proceedings of the National Academy of Sciences 112(19):5979-5984. http://dx.doi.org/10.1073/pnas.1414640112

Levy, S. 2010. Catch shares management. Bioscience 60 (10):780-785. http://dx.doi.org/10.1525/bio.2010.60.10.3

Mancini, A., J. Senko, R. Borquez-Reyes, J. G. Póo, J. A. Seminoff, and V. Koch. 2011. To poach or not to poach an endangered species: elucidating the economic and social drivers behind illegal sea turtle hunting in Baja California Sur, Mexico. Human Ecology 39(6):743-756. http://dx.doi.org/10.1007/s10745-011-9425-8

Mansfield, B. 2004. Neoliberalism in the oceans: "rationalization," property rights, and the commons question. Geoforum 35 (3):313-326. http://dx.doi.org/10.1016/j.geoforum.2003.05.002

Mansfield, B. 2007. Privatization: property and the remaking of nature-society relations introduction to the special issue. Antipode 39(3):393-405. http://dx.doi.org/10.1111/j.1467-8330.2007.00532. $\underline{\mathrm{x}}$

Mansfield, B. 2011. "Modern" industrial fisheries and the crisis of overfishing. Pages 84-99 in R. Peet, P. Robbins, and M. Watts, editors. Global political ecology. Routledge, London, UK.

Martin, P. M. 2005. Comparative topographies of neoliberalism in Mexico. Environment and Planning A 37(2):203-220. http://dx. doi.org/10.1068/a3737

McCarthy, J. 2006. Neoliberalism and the politics of alternatives: community forestry in British Columbia and the United States. Annals of the Association of American Geographers 96(1):84-104. http://dx.doi.org/10.1111/j.1467-8306.2006.00500.x

McCauley, D. J., C. Jablonicky, E. H. Allison, C. D. Golden, F. H. Joyce, J. Mayorga, and D. Kroodsman. 2018. Wealthy countries dominate industrial fishing. Science Advances 4(8): eaau2161. http://dx.doi.org/10.1126/sciadv.aau2161

McCay, B. J. 1984. The pirates of piscary: ethnohistory of illegal fishing in New Jersey. Ethnohistory 31(1):17-37. http://dx.doi. org/10.2307/482021

McCay, B. J. and J. M. Acheson, editors. 1990. The question of the commons: the culture and ecology of communal resources. University of Arizona Press, Tucson, Arizona, USA.

McCay, B. J., F. Micheli, G. Ponce-Díaz, G. Murray, G. Shester, S. Ramirez-Sanchez, and W. Weisman. 2014. Cooperatives, concessions, and co-management on the Pacific coast of Mexico. Marine Policy 44:49-59. http://dx.doi.org/10.1016/j.marpol.2013.08.001

McClanahan, T. R., J. C. Castilla, A. T. White, and O. Defeo. 2009. Healing small-scale fisheries by facilitating complex socioecological systems. Reviews in Fish Biology and Fisheries 19 (1):33-47. http://dx.doi.org/10.1007/s11160-008-9088-8

McClenachan, L., B. P. Neal, D. Al-Abdulrazzak, T. Witkin, K. Fisher, and J. N. Kittinger. 2014. Do community supported fisheries (CSFs) improve sustainability? Fisheries Research 157:62-69. http://dx.doi.org/10.1016/j.fishres.2014.03.016

McGoodwin, J. R. 1976. Society, economy, and shark-fishing crews in rural northwest Mexico. Ethnology 15(4):377-391. http:// dx.doi.org/10.2307/3773306

McGoodwin, J. R. 1987. Mexico's conflictual inshore Pacific fisheries: problem analysis and policy recommendations. Human Organization 46(3):221-232. http://dx.doi.org/10.17730/humo.46.3. ut17332136660242

Meltzer, L., N. S. Blinick, and A. B. Fleishman. 2012. Management implications of the biodiversity and socioeconomic impacts of shrimp trawler by-catch in Bahía de Kino, Sonora, México. PLoS ONE 7(6):e35609. http://dx.doi. org/10.1371/journal.pone.0035609 
Meltzer, L., and J. O. Chang. 2006. Export market influence on the development of the Pacific shrimp fishery of Sonora, Mexico. Ocean \& Coastal Management 49(3-4):222-235. http://dx.doi. org/10.1016/j.ocecoaman.2006.02.009

Méndez, E. 2016. Abaten a pescador furtivo de totoaba que recibía recursos federales. Excelsior, 28 March. [online] URL: https://www.excelsior.com.mx/nacional/2016/03/28/1083300

Méndez-Medina, C., B. Schmook, and S. R. McCandless. 2015. The Punta Allen cooperative as an emblematic example of a sustainable small-scale fishery in the Mexican Caribbean. Maritime Studies 14(1):12. http://dx.doi.org/10.1186/s40152-015-0026-9

Merlijn, A. G. 1989. The role of middlemen in small-scale fisheries: a case study of Sarawak, Malaysia. Development and Change 20(4):683-700. http://dx.doi.org/10.1111/j.1467-7660.1989. $\underline{\text { tb00362.x }}$

Morzaria-Luna, H. N., P. Turk-Boyer, and M. Moreno-Baez. 2014. Social indicators of vulnerability for fishing communities in the Northern Gulf of California, Mexico: implications for climate change. Marine Policy 45:182-193. http://dx.doi. org/10.1016/j.marpol.2013.10.013

Naranjo-Madrigal, H., I. van Putten, and A. Norman-López. 2015. Understanding socio-ecological drivers of spatial allocation choice in a multi-species artisanal fishery: a Bayesian network modeling approach. Marine Policy 62:102-115. http://dx. doi.org/10.1016/j.marpol.2015.09.003

Nayak, P. K., and F. Berkes. 2011. Commonisation and decommonisation: understanding the processes of change in the Chilika Lagoon, India. Conservation and Society 9(2):132-145. http://dx.doi.org/10.4103/0972-4923.83723

Nayak, P. K., and F. Berkes. 2014. Linking global drivers with local and regional change: a social-ecological system approach in Chilika Lagoon, Bay of Bengal. Regional Environmental Change 14(6):2067-2078. http://dx.doi.org/10.1007/s10113-012-0369-3

Nayak, P. K., L. Oliveira, and F. Berkes. 2014. Resource degradation, marginalization, and poverty in small-scale fisheries: threats to social-ecological resilience in India and Brazil. Ecology and Society 19(2):73. http://dx.doi.org/10.5751/ ES-06656-190273

Neis, B., M. Binkley, S. Gerrard, and M. Maneschy. 2005. Changing tides: gender, fisheries and globalisation. Fernwood, Halifax, Nova Scotia, Canada.

Olson, J. 2011. Understanding and contextualizing social impacts from the privatization of fisheries: an overview. Ocean \& Coastal Management 54(5):353-363. http://dx.doi.org/10.1016/j. ocecoaman.2011.02.002

Oman, C. 1999. Globalization, regionalization, and inequality. Pages 36-66 in A. Hurrel and N. Woods, editors. Inequality, globalization and world politics. Oxford University Press, Oxford, UK. http://dx.doi.org/10.1093/0198295669.003.0003

Ostrom, E. 2009. A general framework for analyzing sustainability of social-ecological systems. Science 325 (5939):419-422. http://dx.doi.org/10.1126/science.1172133
Ostrom, E., R. Gardner, and J. Walker. 1994. Rules, games, and common-pool resources. University of Michigan Press, Ann Arbor, Michigan, USA. http://dx.doi.org/10.3998/mpub.9739

Páez-Osuna, F., S. R. Guerrero-Galván, and A. C. RuizFernández. 1998. The environmental impact of shrimp aquaculture and the coastal pollution in Mexico. Marine Pollution Bulletin 36(1):65-75. http://dx.doi.org/10.1016/S0025-326X(98) $\underline{90035-2}$

Pastor, M., and C. Wise. 1997. State policy, distribution and neoliberal reform in Mexico. Journal of Latin American Studies 29(2):419-456. http://dx.doi.org/10.1017/S0022216X97004744

Peck, J., and N. Theodore. 2007. Variegated capitalism. Progress in Human Geography 31(6):731-772. http://dx.doi. org/10.1177/0309132507083505

Peck, J., and A. Tickell. 2002. Neoliberalizing space. Antipode 34 (3):380-404. http://dx.doi.org/10.1111/1467-8330.00247

Peterson, N. D. 2014. Breaking the bounds of rationality: values, relationships, and decision-making in Mexican fishing communities. Conservation and Society 12(3):245-256. http://dx. doi.org/10.4103/0972-4923.145135

Peterson, N. D. 2015. Unequal sustainabilities: the role of social inequalities in conservation and development projects. Economic Anthropology 2(2):264-277. http://dx.doi.org/10.1002/sea2.12030

Phillips, G., L. Kriwoken, and P. Hay. 2002. Private property and public interest in fisheries management: the Tasmanian rock lobster fishery. Marine Policy 26(6):459-469. http://dx.doi. org/10.1016/S0308-597X(02)00026-X

Pinkerton, E. 2017. Hegemony and resistance: disturbing patterns and hopeful signs in the impact of neoliberal policies on smallscale fisheries around the world. Marine Policy 80:1-9. http://dx. doi.org/10.1016/j.marpol.2016.11.012

Pinkerton, E., and R. Davis. 2015. Neoliberalism and the politics of enclosure in North American small-scale fisheries. Marine Policy 61:303-312. http://dx.doi.org/10.1016/j.marpol.2015.03.025

Pinsky, M. L., and M. Fogarty. 2012. Lagged social-ecological responses to climate and range shifts in fisheries. Climatic Change 115(3-4):883-891. http://dx.doi.org/10.1007/s10584-012-0599-x

Platteau, J.-P., and A. Abraham. 1987. An inquiry into quasicredit contracts: the role of reciprocal credit and interlinked deals in small-scale fishing communities. Journal of Development Studies 23(4):461-490. http://dx.doi.org/10.1080/00220388708422044

Pollnac, R. B., and J. J. Poggie. 2008. Happiness, well-being and psychocultural adaptation to the stresses associated with marine fishing. Human Ecology Review 15(2):194-200.

Pomeroy, R. S., and F. Berkes. 1997. Two to tango: the role of government in fisheries co-management. Marine Policy 21 (5):465-480. http://dx.doi.org/10.1016/S0308-597X(97)00017-1

Pramod, G., K. Nakamura, T. J. Pitcher, and L. Delagran. 2014. Estimates of illegal and unreported fish in seafood imports to the USA. Marine Policy 48:102-113. http://dx.doi.org/10.1016/j. marpol.2014.03.019 
Revelo, L. D. M., M. J. E. Maurice, and M. Á. H. García. 2015. El modelo neoliberal en el cooperativismo del sector pesquero artesanal. Revista Mexicana de Ciencias Agrícolas 1:273-279.

Reyes, R. B., O. A. Pombo, and G. P. Díaz. 2009. Fishers' reasons for poaching abalone (Haliotidae): a study in the Baja California Peninsula, Mexico. North American Journal of Fisheries Management 29(1):237-244. http://dx.doi.org/10.1577/M06-032.1

Robles-Zavala, E. 2014. Coastal livelihoods, poverty and wellbeing in Mexico. A case study of institutional and social constraints. Journal of Coastal Conservation 18(4):431-448. http:// dx.doi.org/10.1007/s11852-014-0329-9

Rubio-Cisneros, N. T., O. Aburto-Oropeza, J. Jackson, and E. Ezcurra. 2017. Coastal exploitation throughout Marismas Nacionales Wetlands in northwest Mexico. Tropical Conservation Science 10:1-26. http://dx.doi.org/10.1177/1940082917697261

Saenz-Arroyo, A., C. M. Roberts, J. Torre, M. Cariño-Olvera, and R. Enríquez-Andrade. 2005. Rapidly shifting environmental baselines among fishers of the Gulf of California. Proceedings of the Royal Society of London B: Biological Sciences 272 (1575):1957-1962. http://dx.doi.org/10.1098/rspb.2005.3175

Sala, E., O. Aburto-Oropeza, M. Reza, G. Paredes, and L. G. López-Lemus. 2004. Fishing down coastal food webs in the Gulf of California. Fisheries 29(3):19-25. http://dx.doi.org/10.1577/1548-8446 (2004)29[19:FDCFWI]2.0.CO;2

Salas, S., and D. Gaertner. 2004. The behavioural dynamics of fishers: management implications. Fish and Fisheries 5 (2):153-167. http://dx.doi.org/10.1111/j.1467-2979.2004.00146.x

Schultz, O. J. 2017. The micro-politics of small-scale fisheries governance in South Africa: a case study of community-based political representation as a form of brokerage. Maritime Studies 16(1):7. http://dx.doi.org/10.1186/s40152-017-0060-x

Sievanen, L. 2014. How do small-scale fishers adapt to environmental variability? Lessons from Baja California, Sur, Mexico. Maritime Studies 13(1):9. http://dx.doi.org/10.1186/ $\underline{\mathrm{s} 40152-014-0009-2}$

St. Martin, K. 2007. The difference that class makes: neoliberalization and non-capitalism in the fishing industry of New England. Antipode 39(3):527-549. http://dx.doi.org/10.1111/ j.1467-8330.2007.00538.x

Stoll, J. S., C. M. Beitl, and J. A. Wilson. 2016. How access to Maine's fisheries has changed over a quarter century: the cumulative effects of licensing on resilience. Global Environmental Change 37:79-91. http://dx.doi.org/10.1016/j.gloenvcha.2016.01.005

Swartz, W., U. R. Sumaila, R. Watson, and D. Pauly. 2010. Sourcing seafood for the three major markets: the EU, Japan and the USA. Marine Policy 34(6):1366-1373. http://dx.doi. org/10.1016/j.marpol.2010.06.011

Thorpe, A., A. A. Ibarra, and C. Reid. 2000. The new economic model and marine fisheries development in Latin America. World Development 28(9):1689-1702. http://dx.doi.org/10.1016/S0305-750X (00)00045-0

Valdez-Gardea, G. 2002. People's responses in a time of crisis: marginalization in the upper Gulf of California. Dissertation. The University of Arizona, Tucson, Arizona, USA.
Valdez-Gardea, G. C. 2007. "Soy pescadora de almejas...": Respuesta a la marginación en el alto golfo de California. El Colegio de Sonora, Hermosillo, Sonora, México.

Van Mulekom, L., A. Axelsson, E. P. Batungbacal, D. Baxter, R. Siregar, and I. de la Torre. 2006. Trade and export orientation of fisheries in Southeast Asia: under-priced export at the expense of domestic food security and local economies. Ocean \& Coastal Management 49(9-10):546-561. http://dx.doi.org/10.1016/j. ocecoaman.2006.06.001

Vásquez-León, M. 1994. Avoidance strategies and governmental rigidity: the case of the small-scale shrimp fishery in two Mexican communities. Journal of Political Ecology 1(1):67-82. http://dx. doi.org/10.2458/v1i1.21157

Vásquez-León, M. 1999. Neoliberalism, environmentalism, and scientific knowledge: redefining use rights in the Gulf of California fisheries. Pages 233-260 in J. M. Heyman, editor. States and illegal practices. Berg, Oxford, UK.

Vasquez-Leon, M. 2002. Assessing vulnerability to climate risk: the case of small-scale fishing in the Gulf of California, Mexico. Investigaciones Marinas 30(1):204-205. http://dx.doi.org/10.4067/ $\underline{\mathrm{S} 0717-71782002030100089}$

Vásquez-León, M. 2012. Policies on conservation and sustainable development: fishing communities in the Gulf of California, Mexico. Pages 165-186 in T. Weaver, J. B. Greenberg, W. L. Alexander, and A. Browning, editors. Neoliberalism and commodity production in Mexico. University Press of Colorado, Boulder, Colorado, USA.

Weaver, T., J. B. Greenberg, W. L. Alexander, and A. BrowningAiken, editors. 2012. Neoliberalism and commodity production in Mexico. University Press of Colorado, Boulder, Colorado, USA.

Weeratunge, N., C. Béné, R. Siriwardane, A. Charles, D. Johnson, E. H. Allison, P. K. Nayak, and M. C. Badjeck, 2014. Small-scale fisheries through the wellbeing lens. Fish and Fisheries 15 (2):255-279. http://dx.doi.org/10.1111/faf.12016

Weintraub, S. 1990. A marriage of convenience: relations between Mexico and the United States. Oxford University Press, New York, New York, USA.

Witter, A., and J. Stoll. 2017. Participation and resistance: alternative seafood marketing in a neoliberal lera. Marine Policy 80:130-140. http://dx.doi.org/10.1016/j.marpol.2016.09.023

Young, E. H. 1999. Balancing conservation with development in small-scale fisheries: is ecotourism an empty promise? Human Ecology 27(4):581-620. http://dx.doi.org/10.1023/A:1018744011286

Young, E. H. 2001. State intervention and abuse of the commons: fisheries development in Baja California Sur, Mexico. Annals of the Association of American Geographers 91(2):283-306. http://dx. doi.org/10.1111/0004-5608.00244

Young, O. R., F. Berkhout, G. C. Gallopin, M. A. Janssen, E. Ostrom, and S. Van der Leeuw. 2006. The globalization of socioecological systems: an agenda for scientific research. Global Environmental Change 16(3):304-316. http://dx.doi.org/10.1016/ j.gloenvcha.2006.03.004 